\title{
Spinal RacGAP $\alpha$-Chimaerin Is Required to Establish the Midline Barrier for Proper Corticospinal Axon Guidance
}

\author{
Shota Katori, ${ }^{1}$ Yukiko Noguchi-Katori, ${ }^{1}$ Shigeyoshi Itohara, ${ }^{2}$ and Takuji Iwasato ${ }^{1,3}$ \\ ${ }^{1}$ Division of Neurogenetics, National Institute of Genetics, Mishima, Shizuoka 411-8540, Japan, ${ }^{2}$ Laboratory for Behavioral Genetics, RIKEN Brain Science \\ Institute, Wako, Saitama 351-0198, Japan, and ${ }^{3}$ Department of Genetics, SOKENDAI (The Graduate University for Advanced Studies), Mishima, Shizuoka \\ 411-8540, Japan
}

In the developing CNS, the midline barrier, which comprises guidance molecule-expressing midline glial somata and processes, plays a pivotal role in midline axon guidance. Accumulating evidence has revealed the molecular mechanisms by which the midline barrier ensures proper midline guidance for axons. In contrast, the mechanisms for establishing the midline barrier remain obscure. Here, we report that Rac-specific GTPase-activating protein (RacGAP) $\alpha$-chimaerin is required for both axonal repulsion at and establishment of the midline barrier in the spinal cord. We generated cortex-specific and spinal-cord-specific $\alpha$-chimaerin gene (Chn1) knock-out mice (Cx-Chn1KO and Sp-Chn1K0 mice, respectively) and found that both showed aberrant corticospinal tract (CST) axon midline crossing in the spinal cord. Strikingly, Sp-Chn1KO mice had breaks (holes) in the ephrinB3(+) spinal midline barrier and EphA4(+)CST axons aberrantly crossed the midline through these holes. During normal embryonic development, EphA4 $(+)$ spinal cells are located in juxta-midline areas but are excluded from the midline. In contrast, in Chn1KO embryos, several EphA4(+) cells were aberrantly relocated into the midline and the midline barrier was broken around these cells. Similarly, the spinal cord midline of Epha4KO mice was invaded by juxta-midline EphA4 cells (i.e., Epha4 promoter-active cells) during the embryonic stage and holes were formed in the midline barrier. Juxta-midline EphA4 cells in the spinal cord expressed $\alpha$-chimaerin. We propose that spinal $\alpha$-chimaerin aids in establishing an intact spinal midline barrier by mediating juxta-midline EphA4 $(+)$ cell repulsion, thus preventing these cells from breaking into the ephrinB3(+) midline barrier.

Key words: $\alpha$-chimaerin; cell migration; CNS; midline axon guidance; midline barrier; mouse genetics

\section{Significance Statement}

The midline barrier plays a critical role in midline axon guidance, which is fundamental to the formation of neural circuits that are responsible for proper left-right coordination of the body. Studies have revealed some of the mechanisms underlying how the midline barrier navigates axons. In contrast, the establishment of the midline barrier during embryonic development remains unclear. In this study, we determined that $\alpha$-chimaerin is required for the formation of an intact midline barrier. Spinal-cordspecific $\alpha$-chimaerin knock-out mice had spinal midline barriers with numerous breaks (holes), through which corticospinal axons aberrantly crossed the midline. We propose that $\alpha$-chimaerin protects the midline barrier by mediating cell-repulsive signaling in juxta-midline cells, which prevents these cells from invading the midline.

\section{Introduction}

Proper left-right coordination of bilateria relies on precise wiring of their neural circuits at the midline. In vertebrates, midline glia

\footnotetext{
Received 0ct. 7, 2016; revised May 11, 2017; accepted June 27, 2017.

Author contributions: S.K. and T.I. designed research; S.K. and Y.N.-K. performed research; S.I. contributed unpublished reagents/analytic tools; S.K. and T.I. analyzed data; S.K. and T.I. wrote the paper.

This work was supported by the Japan Society for the Promotion of Science (JSPS; KAKENHI Grants $15 K 14889$ and 13J04498 to S.K. and KAKENHI Grants 16K14559, 15H04263, 15H01454, and 22115009) and the Ministry of Education, Culture, Sports, Science and Technology (MEXT Grant in Scientific Research on Innovation Areas 16H06459 "Dynamic Regulation of Brain Function by Scrap and Build System"); and the Brain Research Institute of Niigata University (Collaborative Research Project 2016-2610 to T.I.). We thank Ryohei Iwata, Yasushi Hiromi, Toshikuni Sasaoka, Hiroshi Nishimaru, Hidenobu Mizuno, Ramasamy Kandasamy, Wenshu Luo, Shingo Nakazawa, and Ayumi Suzuki for discussion and/or comments on the manuscript; Hidenobu Mizuno for technical instruction of in utero
}

arrange their cell bodies and processes in a sheet to form the midline barrier $(\mathrm{MB})$, which separates commissural and noncommissural axons (Snow et al., 1990; McDermott et al., 2005; Marichal et al., 2012; Sakai and Kaprielian, 2012). During devel-

electroporation; Takuya Sato, Minako Kanbayashi, and Satoko Kouyama for technical assistance; Marc TessierLavigne (Rockefeller University) and Mitsuhiro Hashimoto (Fukushima Medical University) for Epha4-LacZ mice (MMRCC 30744); Hanns Ulrich Zeilhofer (University of Zurich) and Kohichi Tanaka (Tokyo Medical and Dental University) for Hoxb8-Cre mice; and Masaru Okabe (Osaka University) for pCX-EGFP.

The authors declare no competing financial interests.

Correspondence should be addressed to Takuji I wasato: Division of Neurogenetics, National Institute of Genetics (NIG), 1111 Yata, Mishima, Shizuoka 411-8540, Japan. E-mail: tiwasato@nig.ac.jp.

DOI:10.1523/JNEUROSCI.3123-16.2017

Copyright $\odot 2017$ the authors $\quad 0270-6474 / 17 / 377682-18 \$ 15.00 / 0$ 
opment, contralaterally projecting axons enter the midline by recognizing attractive cues secreted by midline glia and subsequently depart from the midline to the opposite side by recognizing repulsive cues from midline glia (Chédotal, 2011). For example, commissural axons originating from the dorsal spinal cord in mice navigate toward the ventral midline by attractive cues (e.g., netrin- 1 and Sonic Hedgehog) secreted by ventral midline glia (floor plate cells) (Serafini et al., 1996; Charron et al., 2003; Chédotal, 2011). Subsequently, these axons are driven out of the midline to the contralateral side by repulsive cues (such as Slit) expressed by midline glia (Long et al., 2004; Pignata et al., 2016). In contrast, axons that should not cross the midline are prevented from entering the midline by expressing receptors for repulsive cues presented on midline glial somata and processes. For example, in the optic chiasm of the mouse, midline glia express ephrinB2 to repel axons of ipsilaterally projecting retinal ganglion cells that express EphB1 (Erskine and Herrera, 2014). In the spinal cord of the mouse, midline glia express ephrinB3 to repel corticospinal tract (CST) axons that express EphA4 (Coonan et al., 2001; Kullander et al., 2001a, b; Yokoyama et al., 2001). As described above, research has furthered our understanding of the molecular mechanisms by which the MB sorts axons for proper midline guidance. In contrast, how the MB itself is established during development remains unclear.

Rac-specific GTPase-activating protein (RacGAP) $\alpha$-chimaerin is a negative regulator of Rac that controls actin cytoskeleton dynamics (Kozma et al., 1996). Both spontaneous and targeted mutations of the $\alpha$-chimaerin gene (Chn1) in mice led to aberrant midline crossing of CST axons, abnormal spinal central pattern generators, and a rabbit-like hopping gait (Beg et al., 2007; Iwasato et al., 2007; Wegmeyer et al., 2007). These phenotypes of $\alpha$-chimaerin-deficient mice are similar to those of EphA4-deficient (Dottori et al., 1998; Coonan et al., 2001; Kullander et al., 2001a, 2003) and ephrinB3deficient (Kullander et al., 2001b; Yokoyama et al., 2001; Kullander et al., 2003) mice. In fact, $\alpha$-chimaerin is a key mediator of ephrinB3-EphA4 forward signaling. $\alpha$-Chimaerin interacts with EphA4 in vivo and in vitro and inactivates Rac activity in response to ephrinB3-EphA4 forward signaling in vitro (Iwasato et al., 2007; Wegmeyer et al., 2007). Inactivation or suppression of $\alpha$-chimaerin in cultured neurons inhibits ephrinB3induced growth cone collapse (Iwasato et al., 2007; Wegmeyer et al., 2007).

In the present study, we first analyzed cortex-specific $C h n 1$

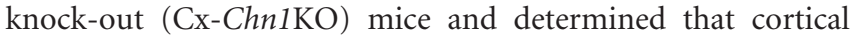
$\alpha$-chimaerin is essential for proper CST axon midline guidance. These data confirmed the important role of axonal $\alpha$-chimaerin in EphA4-dependent axonal repulsion at the ephrinB3(+) MB. Next, we generated spinal-cord-specific Chn1KO (Sp-Chn1KO) mice. We showed that spinal $\alpha$-chimaerin plays a critical role for $\mathrm{MB}$ establishment. We found that numerous breaks were present in the spinal MB in Sp-Chn1 KO mice and CST axons aberrantly crossed the midline through these breaks. During embryonic development of normal mice, spinal EphA4 $(+)$ cells located in the midline vicinity expressed $\alpha$-chimaerin. In ChnlKO mice, these cells accumulated in the midline and breaks in the $\mathrm{MB}(\mathrm{MB}$ holes) emerged around these cells. Our results indicate that spinal $\alpha$-chimaerin is essential for establishing an intact spinal MB and excluding juxta-midline EphA4(+) cells from the midline may be the key step for establishing an intact MB. Here, we shed light on the mechanism of $\mathrm{MB}$ formation during development, which includes a critical role of ephrinB3-EphA4- $\alpha$-chimaerin signaling in cell repulsion.

\section{Materials and Methods}

Animals. We previously generated Chn1 mutant mice that possess $C h n 1^{-}$(Iwasato et al., 2007), Chn1 ${ }^{\text {flox }}, C h n 1^{\Delta \alpha 1}$, or $C h n 1^{\text {flox } \alpha 2}$ alleles (Iwata et al., 2014), Emx1-Cre KI- $\Delta$ Neo mice (Iwasato et al., 2000; Iwasato et al., 2008), and Rosa26-NLS-lacZ (RNZ) reporter mice (Kobayashi et al., 2013). Hoxb8-Cre transgenic mice (Witschi et al., 2010) and EphA4-LacZ gene trap mice (Leighton et al., 2001) were kindly gifted.

For the analyses shown in Figures 1, 3, and 4,Emx1 ${ }^{+/ \mathrm{Cre}} ; \mathrm{Chn} 1^{\text {flox/ - }}$ $(\mathrm{Cx}-\mathrm{Chn} 1 \mathrm{KO})$ and $\mathrm{Chn} 1^{\text {flox } /-}$ (control) mice were used. For the analyses shown in Figures 1, 2, and 3, Hoxb8-Cre;Chn1 flox/- (Sp-Chn1KO) and Hoxb8-Cre;Chn1 flox/+ (control) mice were used. For the analyses shown in Figure 3, Hoxb8-Cre;Chn1 flox $\alpha 21-(S p-\alpha 2 C h n K O)$ and $C h n 1^{\Delta \alpha 1 / \Delta \alpha 1}(\alpha 1 C h n K O)$ mice were used. Sp-Chn1KO and their control mice contain RNZ reporter, which were used for confirmation of spinal-cord-specific Cre-mediated recombination. For the analyses shown in Figure 4, Hoxb8-Cre;Chn1 ${ }^{\text {flox } /-}(\mathrm{Sp}-\mathrm{Chn1 \textrm {KO }})$ mice were used. For the analyses shown in Figures 1, 3, and 6, Chn1 ${ }^{-1-}(\mathrm{Chn} 1 \mathrm{KO})$ and $\mathrm{Chn1}^{+/-}$(control) mice were used. For the analyses shown in Figures 8, 9, and 10, Epha4 ${ }^{\text {LacZ/LacZ }}$ (Epha4KO) and Epha4 ${ }^{+/ L a c Z}$ (control) mice were used. For the analyses shown in Figures 5, 7, and 9, Chn1 ${ }^{-1-}$; Epha4 $^{+/ \mathrm{LacZ}}(\mathrm{Chn} 1 \mathrm{KO})$ and Chn1 ${ }^{+/-} ;$Epha4 ${ }^{+/ \mathrm{LacZ}}$ (control) mice were used.

All of the experimental procedures were based on the Guide for the Care and Use of Laboratory Animals of the Science Council of Japan and were approved by the Animal Experiment Committee of National Institute of Genetics.

Analysis of CST axons labeled by an anterograde tracer. The mice were anesthetized by $1.9 \%$ isoflurane (DS Pharma Animal Health) at a $260 \mathrm{ml} /$ min flow rate (model 410 anesthesia unit adapted for air pump; Univentor) in adulthood. The heads were fixed with a stereotaxic instrument $(\mathrm{Na}-$ rishige), the head skins were incised, and skulls were unilaterally removed partially. Biotinylated dextran amine (BDA, 15\%, invitrogen) in $0.01 \mathrm{M}$ phosphate buffer $(\mathrm{PB}), \mathrm{pH} 7.4$, was unilaterally injected to the motor and somatosensory cortices $(0.2 \mu \mathrm{l} /$ site into $6-8$ injection sites) that innervate cervical cord (Kamiyama et al., 2015). The skull-removed cortex was then covered with petrolatum and the skin was sutured with silk thread. After 2-3 weeks, the mice were killed with isoflurane and transcardially perfused with saline and $4 \%$ paraformaldehyde (PFA; Nacalai) in $0.1 \mathrm{M} \mathrm{PB}$. The spinal cord was taken out from the spinal column and postfixed in $4 \% \mathrm{PFA} / 0.1 \mathrm{M} \mathrm{PB}$ for $6-8 \mathrm{~h}$ and subsequently immersed in $30 \%$ sucrose $/ 0.1 \mathrm{M} \mathrm{PB}$ for $>2 \mathrm{~d}$. From the cervical segments, $60-\mu \mathrm{m}$-thick coronal sections were prepared with a freezing microtome (Yamato Kohki).

For analysis of the BDA-labeled CST axons in cervical segment 5 (C5) of Cx-Chn1KO mice $(n=7), C h n 1 \mathrm{KO}$ mice $(n=4)$, and their controls $\left(C h n 1^{\text {flox } /-}, n=6\right)$, the axons were colored with VECTASTAIN Elite ABC Kit (Vector Labs) and DAB Substrate Kit (Vector Labs), traced with a camera lucida (Leica) mounted on an upright microscope (DMR; Leica), and retraced and measured with NeuronJ (Meijering et al., 2004), a plugin for ImageJ software. In another set of BDA-labeled CST axons in C5 of Cx-Chn1KO mice $(n=3), C h n 1 \mathrm{KO}$ mice $(n=5)$, and their controls $\left(\mathrm{Chnl}^{+{ }^{+-}}, n=5\right)$, spinal sections were incubated in Streptavidin, Alexa Fluor 488 conjugate (1:400; Life Technologies) for $2 \mathrm{~h}$ (Omoto et al., 2011). $z$-stack images of the Alexa Fluor 488-colored CST axons were taken with a confocal microscope (SP5; Leica) and traced with Simple Neurite Tracer (Longair et al., 2011), a plugin for ImageJ. For detection of the BDA-labeled CST axons in C8 of Sp-Chn1KO mice $(n=$ 7), Chn1KO mice $(n=6)$, and their controls $(n=8: 5$ Hoxb8-Cre; $\mathrm{Chn1} \mathrm{I}^{\text {flox/+ }}$ and $3 \mathrm{Chn1}^{+/-}$), all of the spinal sections were incubated in Streptavidin, Alexa Fluor 488 conjugate, and axons were traced with Simple Neurite Tracer as mentioned above.

For the quantification of CST axons that crossed the spinal midline in Figure 1, the areas of midline and adjacent contralateral and ipsilateral dorsal gray matter (DGM) were delimited using a previously reported method (Iwasato et al., 2007). Briefly, the height of each area was defined as the distance from the ventral tip of the dorsal funiculus (DF) to the center of the central canal (CC) and the width was defined as the lateral extent of the CC ependymal cell layer. The ipsilateral side was the BDAinjected side and the contralateral side was the uninjected side. The ratio 
of axonal length in the ipsilateral area to that in the contralateral area was calculated in each section.

Morphological analysis of DGM midline length. In adulthood, SpChn1KO mice and their controls were transcardially perfused with saline and $4 \%$ PFA/0.1 м PB and the spinal columns were taken out. Then, the dorsal parts of spinal columns were removed and the dorsal surfaces of the spinal cords were exposed and immersed in $4 \%$ PFA/0.1 м PB for $6-8 \mathrm{~h}$ and in $30 \%$ sucrose $/ 0.1 \mathrm{~m} \mathrm{~PB}$ for $>2 \mathrm{~d}$. Finally, the spinal cords were taken out from the spinal columns. Coronal sections (100 $\mu$ m-thick) of the C6 were mounted on Frontier-coated glass slides (FRC-01; Matsunami). The sections were applied with PBS, pH 7.4, and covered with cover glasses (Matsunami). The images were obtained with cooled CCD camera (VB-7010; Keyence) mounted on the upright microscope (DMR; Leica). Midline lengths of the DGM and DF, which were defined as distances between the center of CC and the ventral tip of the DF and that between the DF ventral tip and the dorsal surface of the spinal cord, respectively, were measured. The midline length ratio of DGM and DGM + DF was calculated in each section.

Antibodies. Rabbit anti-ephrinB3 (1:100 or 1000; Life Technologies), mouse anti-nestin (1:100; Santa Cruz Biotechnology), rat anti-CD31/ PECAM1 (1:500; Novus Biologicals), mouse anti- $\beta$-galactosidase ( $\beta$-gal, $1: 100$; Promega), anti-NeuN (1:1000; Millipore), and rabbit anti- $\alpha 2-$ chimaerin (1:10,000, $\alpha 2-1$ fraction 5; Iwata et al., 2015) were used as primary antibodies. Alexa Fluor 568 (or 647) goat anti-rabbit IgG $(\mathrm{H}+\mathrm{L}$ ) (1:1000; Invitrogen), Alexa Fluor 488 (or 568) goat anti-mouse IgG $(\mathrm{H}+\mathrm{L})(1: 1000$; Invitrogen), and Alexa Fluor 488 goat anti-rat IgG $(\mathrm{H}+\mathrm{L})(1: 1000$; Invitrogen) were used as secondary antibodies.

Immunohistochemistry and histological analyses. Embryonic day 14.5 (E14.5), E15.5, and E17.5 mice and postnatal day 0 (P0) and P5 mice were transcardially perfused with saline. Then, the dorsal part of the spinal column was removed and the dorsal surface of the spinal cord was exposed and immersed in $4 \% \mathrm{PFA} / 0.1 \mathrm{M}$ PB for $6-8 \mathrm{~h}$ and in $30 \%$ sucrose/ $0.1 \mathrm{M}$ PB for $>2 \mathrm{~d}$. Finally, the spinal cord was taken out from the spinal column. For the analyses shown in coronal sections, $100-\mu \mathrm{m}$-thick sections were made with the freezing microtome from the spinal cord that was frozen in $30 \%$ sucrose/0.1 M PB with solid carbon dioxide/ethanol. For the analyses shown in spinal midsagittal sections, spinal cord that was placed in Cryomolds (Sakura Finetek) filled with optimal cutting temperature (OCT) compound (Sakura Finetek) was frozen with solid carbon dioxide/isopentane and $100-\mu \mathrm{m}$-thick sections were made with a cryostat (CM3050 S; Leica).

For immunohistological analyses shown in Figures 2, 3, 4, 5, 7, 8, and 10 , the spinal sections ( $100 \mu \mathrm{m}$ thick) were reacted with primary antibodies in PBS containing $0.25 \%$ Triton X-100 and $1.5 \%$ goat serum at $4^{\circ} \mathrm{C}$ for $>1 \mathrm{~d}$ and reacted with secondary antibodies in PBS containing $0.25 \%$ Triton X-100, $1.5 \%$ goat serum, and $1 \mu \mathrm{g} / \mathrm{ml} 4^{\prime}, 6$-diamidino-2phenylindole (DAPI) at $4^{\circ} \mathrm{C}$ for $>1 \mathrm{~d}$. For the $\alpha 2$-chimaerin and $\beta$-gal double staining shown in Figure 9, the spinal sections (100 $\mu \mathrm{m}$ thick) were pretreated with $3 \% \mathrm{H}_{2} \mathrm{O}_{2} / \mathrm{PBS}$ for $20 \mathrm{~min}, 0.1 \mathrm{mg} / \mathrm{ml}$ pepsin in $0.2 \mathrm{~N}$ $\mathrm{HCl}, 0.1 \mathrm{M} \mathrm{PB}$ for $15 \mathrm{~min}$, and PBS containing $0.1 \%$ Triton X-100 and $10 \%$ goat serum for $1 \mathrm{~h}$. These sections were then incubated in rabbit anti- $\alpha 2$-chimaerin and mouse anti- $\beta$-gal antibodies at $4{ }^{\circ} \mathrm{C}$ for $>2 \mathrm{~d}$ and incubated in biotinylated anti-rabbit IgG antibody (1:200, Vectastain Elite ABC Kit; Vector Labs), Alexa Fluor 568 goat anti-mouse IgG antibody (1:1000), and $1 \mu \mathrm{g} / \mathrm{ml}$ DAPI for $>2 \mathrm{~d}$. The biotin was detected with the Vectastain Elite ABC kit and the TSA Plus Fluorescein System (PerkinElmer).

LacZ staining for Figure $1 C$ was performed with in $\mathrm{X}$-gal solution ( $5 \mathrm{~mm} \mathrm{~K}_{3} \mathrm{FeCN}_{6}, 5 \mathrm{~mm} \mathrm{~K}_{4} \mathrm{FeCN}_{6}, 2 \mathrm{~mm} \mathrm{MgCl}_{2}, 1 \mathrm{mg} / \mathrm{ml} \mathrm{X}$-gal in $0.1 \mathrm{M} \mathrm{PB}$ ) at $37^{\circ} \mathrm{C}$.

Analyses of $M B$ holes. Each single-plane coronal image shown in Figures $2,4,5,7$, and 8 was obtained using a confocal microscope. For each $z$-projection midsagittal image in Figure 3, serial single-plane images were obtained from a midsagittal section using the $z$-compensation function of the confocal microscope. In each single-plane image, the MB area was identified using ephrinB3 signal and cropped using ImageJ. Cropped images were subjected to $z$-projection (ImageJ). For each pseudomidsagittal image in Figures 3, 4, 5, 7, and 8, serial single-plane coronal images were obtained from a coronal section using the $z$-compensation function of the confocal microscope. The $z$-stack image was then virtu- ally sliced along the midsagittal plane using the Reslice function of ImageJ. Resliced images were subjected to $z$-projection (ImageJ). The resulting pseudo-midsagittal images (Figs. $4,7,8$ ) were used to measure the area of the $\mathrm{MB}$ and $\mathrm{MB}$ holes. For the quantification of MB hole size, ephrinB3 signals in z-projection midsagittal images of P0 Sp-Chn1KO mice (Fig. 3) were used. The longitudinal length of an MB hole was defined as the length of the longitudinal axis, which is the line between the dorsal and ventral tips of the MB hole. The transverse length was defined as the maximum length of the axis orthogonal to the longitudinal axis.

Analyses of $\beta$-gal $(+)$ cell position. For the analyses shown in $\beta$-gal $(+)$ cell position in EphA4-LacZ mice in Figures 7, 8, and 10, spinal coronal sections ( $100 \mu \mathrm{m}$ thick) were stained with anti- $\beta$-gal and anti-ephrinB3 antibodies and DAPI. The confocal images $(0.49 \mu \mathrm{m}$-interval $z$-positions) were obtained. The cells, in which $\beta$-gal immunosignals surrounding nuclei were detected in serial $z$-positions, were defined as $\beta$-gal $(+)$ cells. To determine whether each $\beta$-gal $(+)$ cell is located in the MB or in MB holes, we analyzed both coronal and dorsoventral (DV) images. Number of $\beta$-gal $(+)$ cells in the $\mathrm{MB}$ and that in the $\mathrm{MB}$ holes were counted. For quantification of number of $\beta$-gal $(+)$; $\mathrm{NeuN}(+)$ cells in Figure 6 , spinal coronal sections (100 $\mu \mathrm{m}$ thick) were stained with anti- $\beta$-gal and anti-ephrinB3 antibodies and DAPI.

DNA constructs. For preparation of template DNA for in situ hybridization probes, Epha4 or Efnb3 genes were amplified by PCR with cDNA synthesized from a P2 mouse brain. Primer pairs were designed using the open database of Allen Brain Atlas (for Epha4: 5'-GGTATAAGGACAACTTCACGGC-3', 5' -CTTCTGTGGTATAAACCGAGCC-3'; for Efnb3: 5'-GTTAGGTTTTGCGGGGCT-3'， 5' -TTCCTAGCTCCCCAGGCT$\left.3^{\prime}\right)$. The amplicons inserted into pGEM-T Easy Vector (Promega) were confirmed by sequencing with ABI PRISMR 3130xl, and pGEM-Epha4 (pK258) and pGEM-Efnb3 (pK100) vectors were obtained.

Farnesylation signal-tagged proteins are trafficked to membranes of all neurites (Badaloni et al., 2007; Cai et al., 2013). Fanesylation signaltagged tdTomato (tdT) expression vector, pCX-tdTomato-farnesylation signal (pCX-tdTf) (pK261), was generated as follows: First, the SalI site was removed from the pCX-EGFP (Kato et al., 1999) by SalI digestion and filling and pCX-EGFP $\Delta$ SalI (pK259) was obtained. Second, Egfp was removed from pK259 by EcoRI digestion and the farnesylation signalfused EGFP coding sequence was inserted in turn by Gibson Assembly (New England Biolabs) and pCX-EGFPf (pK260) was generated. Finally, the Egfp in pK260 was replaced with tdTomato by using SalI/SphI sites and Gibson Assembly and pK261 was obtained. The farnesylation signalfused EGFP coding sequence was amplified by two times PCR (first, 5' -CGCCACCATGGTGAGCAAGGGCGAGGAGCTGTTCACC-3', 5' gccggggccactctcatcaggagggttcagcttgcatgcCTTGTACAGCTCGTCCATGCC-3'; second, 5' -TCTCATCATTTTGGCAAAGtcgaCGCCACCATGGTGAGCAAG-3, 5' -GCCTGCACCTGAGGAGTGAtaTCtcaggagagcacacagcagctcatgcagccggggccactctcatc- $\left.3^{\prime}\right)$. The tdTomato was amplified from ptdTomato-N1 vector (Clontech) by PCR (5' -TCTCATCATTTTGGCAAAGtcgaccatggtgagcaaggg-3', 5' -agggttcagcttgcatgccttgtacagctcgtccatgccg-3').

In situ hybridization. In situ hybridization in Figure 6 was performed as described previously with some modifications (Schaeren-Wiemers and Gerfin-Moser, 1993; Katori et al., 2009). After restriction enzyme digestion of pK258 and pK100, RNA probes were synthesized with DIG RNA Labeling Kit (SP6/T7) (Roche). The cervical spinal cords of Chn1 ${ }^{-1-}$ and $C h n 1^{+/-}$mice (E13.5, E14.5, and E15.5) placed in Cryomolds filled with OCT compound were frozen with solid carbon dioxide/ isopentane. Coronal sections ( $10 \mu \mathrm{m}$ in thickness) prepared by the cryostat were thaw-mounted on MAS-coated glass slides (S9442; Matsunami). After hybridization of the RNA probes to the sections for $>12 \mathrm{~h}$, the DIG was detected by anti-Digoxigenin-AP, Fab fragments (Roche) and colored by BCIP-NBT Solution Kit (Nacalai). Nissl staining was used as a counterstain for adjacent sections. The images were obtained by the cooled CCD camera mounted on the upright microscope. Epha4 $(+)$ cells in the dorsal midline (width: $15 \mu \mathrm{m}$ ) were counted in each section.

Analysis of CST axons labeled by in utero electroporation. For the analyses shown in CST axons in Sp-Chn1KO and Cx-Chn1KO embryos in Figure 4, timed mating of Chn1 $1^{\text {flox/+ }}$ female mice with HoxB8-Cre; 
$\mathrm{Chn} 1^{+/-}$male mice and that of Chn $1^{\text {flox/++}}$ female mice with $E m x 1^{+/ C r e}$; $C h n 1^{+/-}$male mice, respectively, was performed. The Chn1 ${ }^{\text {flox/+ }}$ female mice were anesthetized by pentobarbital (Somnopentyl; Kyoritsu Seiyaku) at pregnancy day 13.5. The uteri were taken out with laparotomy and pK261 $(1.0 \mu \mathrm{g} / \mathrm{ml})$ in $0.9 \% \mathrm{NaCl}$ solution including 10\% Trypan blue stain (Invitrogen) was injected unilaterally into the lateral ventricle of the embryos with glass needles. Voltage ( $40 \mathrm{~V}, 50 \mathrm{~ms}$ per $1 \mathrm{~s}, 5$ times; Nepagene) was applied to the cerebra by tweezer-type disk electrodes (BEX). The pups at P5 were perfused by saline and fixed by $4 \%$ PFA/ $0.1 \mathrm{M}$ PB. Coronal sections (100 $\mu \mathrm{m}$ in thickness) of the lower cervical cord were made and stained by anti-nestin antibody (or anti-ephrinB3 antibody) and DAPI by the above-mentioned method. Serial $z$-stack images (interval, $0.49 \mu \mathrm{m}$; thickness, $34.3 \mu \mathrm{m}$ ) of the sections were taken with the confocal microscope. From the serial images, 3D images were constructed with $3 \mathrm{D}$ viewer, a plugin for ImageJ. In each section, all of $\mathrm{tdT}(+)$ midline-crossing axons in Sp-Chn1KO mice were traced with Simple Neurite Tracer. Then, it was determined whether individual $\operatorname{tdT}(+)$ axons crossed the midline through nestin(+) $\mathrm{MB}$ or through nestin(-) MB holes. The ratio of $\mathrm{MB}$ hole-crossing axons to total midline-crossing axons was calculated in each section.

Analysis of unilaterally labeled spinal cord by in utero electroporation. For the analyses shown in Epha4 ${ }^{\text {LacZ/LacZ }}$ embryos in Figure 10, timed mating of Epha4 ${ }^{+/ \text {LacZ }}$ male mice with Epha4 ${ }^{+/ \text {LacZ }}$ female mice was performed. The Epha4 ${ }^{+/ \mathrm{LacZ}}$ female mice were anesthetized at pregnancy day 11.5 by pentobarbital. The uteri were taken out with laparotomy and pCX-EGFP $(1.0 \mu \mathrm{g} / \mathrm{ml})$ in $0.9 \% \mathrm{NaCl}$ solution containing 10\% Trypan blue stain was injected into the fourth ventricle of the embryos at E15.5 with glass needles until the dye was spread into the primitive lumen of the cervical cord. Voltage ( $30 \mathrm{~V}, 50 \mathrm{~ms}$ per $1 \mathrm{~s}, 5$ times) was applied unilaterally to the spinal cords with tweezer-type U-shape platinum electrodes (BEX). The embryos at E17.5 were perfused and fixed with $4 \% \mathrm{PFA} / 0.1 \mathrm{M}$ PB. From the lower cervical cord, $100-\mu$ m-thick coronal sections were made with the freezing microtome. The sections were stained with antiephrinB3 and anti- $\beta$-gal antibodies and DAPI. From the sections, serial $z$-stack images were obtained with the confocal microscope. For the quantification of $\operatorname{GFP}(+)$ cells, a rectangle with $160 \mu \mathrm{m}$ width centered on the midline and with height defined from the ventral tip of the DF to the dorsal edge of the CC was delineated as the region of interest (ROI) in each section. In the ROI, the ephrinB3(+) MB area was defined as the midline area. An area adjacent to the ROI on the electroporated side was defined as the ipsilateral area and the other side was defined as the contralateral area. In each area, the number of $\mathrm{GFP}(+)$ cells was counted. $\mathrm{GFP}(+)$ cells were examined for $\beta$-gal expression. The midline area had three types of cells: (1) GFP $(+) ; \beta-\operatorname{gal}(-)$ cells that extended their processes along the DV axis, which were defined as midline radial glia, (2) $\mathrm{GFP}(+) ; \beta$-gal $(-)$ cells that extended their processes orthogonally to the DV axis, and (3) GFP $(+) ; \beta$-gal $(+)$ cells that extended their processes orthogonally to the DV axis. The $\mathrm{GFP}(+) ; \beta$-gal $(+)$ cells were counted in Epha4KO (Epha4 ${ }^{\text {LacZ/LacZ })}$ and control $\left(E p h a 4^{+/ L a c Z}\right)$ mice. The ratio of the number of $\operatorname{GFP}(+) ; \beta$-gal $(+)$ cells in the midline (or contralateral) area to the total number of $\operatorname{GFP}(+) ; \beta$-gal $(+)$ cells $[\mathrm{GFP}(+) ; \beta$-gal $(+)$ cells in the midline, contralateral, and ipsilateral areas] was calculated for each section.

Experimental design and statistical analyses. In analyses of postnatal mice, both male and female mice were used. In analyses of embryos, their sexes were not determined. For statistical analyses, Prism 5 software (GraphPad) and ystat2002 software (Igaku Tosho Shuppan) were used. For all experiments, significance was set at $p<0.05$.

In analysis of midline-crossing CST axons labeled by an anterograde tracer (see Fig. 1B), Cx-Chn1KO mice ( $n=10$ mice, 10 females; Chn1KO mice, $n=9$ mice, 4 males and 5 females; and control mice, $n=11$ mice, 3 males and 8 females) were used. In analysis of midline-crossing CST axons (see Fig. 1E), Sp-Chn1 KO ( $n=7$ mice, 5 males and 2 females; Chn1 KO mice, $n=6$ mice, 1 male and 5 females; and control mice, $n=$ 8 mice, 4 males and 4 females) were used. For each animal, values of two to three sections were averaged. Statistical analyses of three groups were done with Kruskal-Wallis test and followed by Dunn's multiplecomparisons test.
In morphological analysis of DGM midline length (see Fig. $2 B$ ), SpChn1KO mice ( $n=5$ mice, 1 male and 4 females) and control mice $(n=$ 4 mice, 1 male and 3 females) were used. For each animal, values of two sections were averaged. Statistical analysis was performed with Welch's $t$ test.

In analysis of CST axons labeled by in utero electroporation (see Fig. $4 D$ ), seven sections from two female Sp-Chn1 KO mice were used. Statistical analysis between the number ratio of $\mathrm{MB}$ hole-crossing axons to total midline-crossing axons and the area ratio of MB hole to DGM midline was performed with paired $t$ test.

In analysis of Epha4 $(+)$ cells in the midline (see Fig. $6 F$ ), Chn1KO mice ( $n=12$ sections from 2 mice) at E14.5 and their control mice $(n=$ 12 sections from 2 mice) and Chn1KO mice at E15.5 ( $n=12$ sections from 2 mice) and their control mice ( $n=12$ sections from 2 mice) were used. Statistical analyses between two groups were performed with Welch's $t$ test.

In the analyses of $\beta$-gal $(+)$ cell position (see Fig. $7 H$ ), five sections from three $C h n 1 \mathrm{KO}$ mice were used. In analyses of $\beta$-gal $(+)$ cell position (see Fig. $8 H$ ), 5 sections from 5 Epha4KO mice ( $n=3$ males and 2 females) were used. Statistical analyses between number ratio of $\beta$-gal $(+)$ cells in the $\mathrm{MB}$ holes and those in the DGM MB and area ratio of MB hole and MB DGM were performed with paired $t$ test.

In the analysis of unilaterally labeled spinal cord by in utero electroporation (see Fig. $10 R, S), E p h A 4 \mathrm{KO}$ mice ( $n=8$ sections from 4 mice) and their control mice ( $n=5$ sections from 3 mice) were used. Statistical analyses were performed with Mann-Whitney $U$ test.

\section{Results}

Corticospinal axons show aberrant midline crossing in the dorsal spinal cord in both cortex-specific and spinal-cord-specific

\section{Chn1KO mice}

We have reported previously that spontaneous (Miffy) and targeted $\alpha$-chimaerin mutant mice, in which $C h n 1$ is disrupted in all cells of the body, exhibit aberrant midline crossing of CST axons in the dorsal spinal cord (Iwasato et al., 2007). $\alpha$-Chimaerin is expressed in both cortical neurons and spinal cells (Hall et al., 2001; Wegmeyer et al., 2007). To dissociate the cortical and spinal roles of $\alpha$-chimaerin in CST axon guidance, we generated CxChn1KO $\left(E m x 1^{+/ C r e} ; C h n 1^{\text {flox/- }}\right)$ mice using Emx1-Cre mice, which show Cre-mediated recombination in all cortical excitatory neurons (Iwasato et al., 2000; Iwata et al., 2014; Iwata et al., 2015). We injected an anterograde tracer into the motor cortex of $\mathrm{Cx}-\mathrm{Chn} 1 \mathrm{KO}, \mathrm{Chn} 1 \mathrm{KO}$, and control mice, and analyzed CST projections in the spinal cord. CST axons aberrantly crossed the dorsal spinal midline in both $\mathrm{Cx}-\mathrm{Chn} 1 \mathrm{KO}$ and $\mathrm{Chn} 1 \mathrm{KO}$ mice (Fig. 1A). The extent of aberrant midline crossing in $\mathrm{Cx}-\mathrm{Chn} 1 \mathrm{KO}$ and Chn1KO mice was significantly higher than that in control mice and no significant difference was detected between $\mathrm{CX}$ Chn1KO and Chn1KO mice (Kruskal-Wallis test: $p<0.0001$, Kruskal-Wallis statistic $=19.01$; Dunn's multiple-comparisons

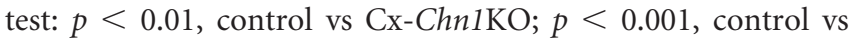
Chn1KO; and ns, Cx-Chn1KO vs Chn1KO; Fig. 1B). These results indicate that cortical-neuron-derived $\alpha$-chimaerin is required to prevent aberrant midline crossing of CST axons.

To examine the role of spinal $\alpha$-chimaerin, we generated SpChn1KO (Hoxb8-Cre;Chn1 ${ }^{\text {flox/- }}$ ) mice using a Hoxb8-Cre line (Witschi et al., 2010). In this line of Cre mice, Cre-mediated recombination occurred in $\mathrm{C} 5$ and in caudal segments of the spinal cord, but not in the cortex (Fig. 1C), as described previously (Witschi et al., 2010). To investigate CST axon projection in $\mathrm{Sp}-\mathrm{Chn} 1 \mathrm{KO}$ mice, we injected an anterograde tracer into the motor cortices of Sp-Chn1KO,Chn1KO, and control mice. Both $\mathrm{Sp}-\mathrm{Chn} 1 \mathrm{KO}$ and $\mathrm{Chn} 1 \mathrm{KO}$ mice displayed aberrant midline crossing of CST axons in the dorsal midline of the caudal segments of 
A

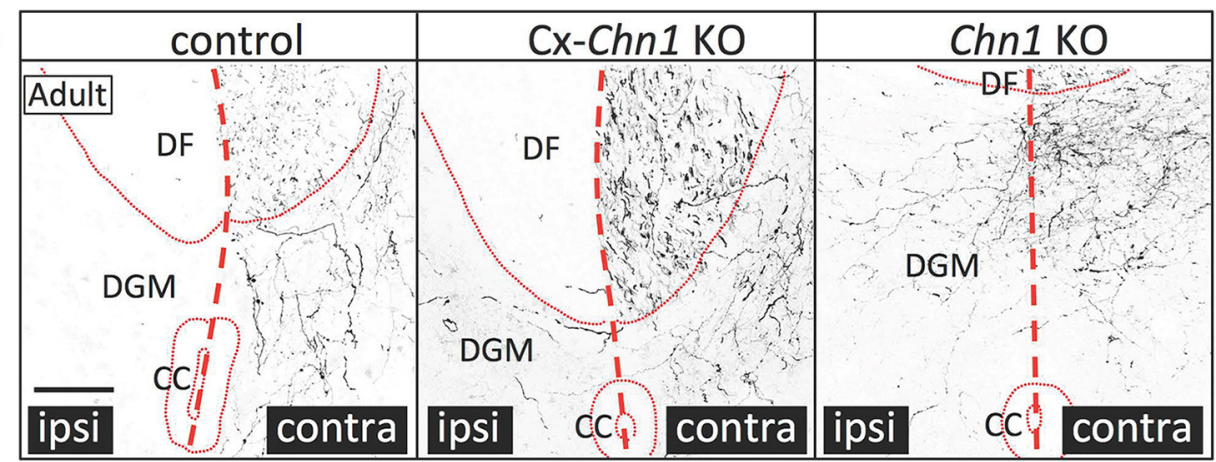

B
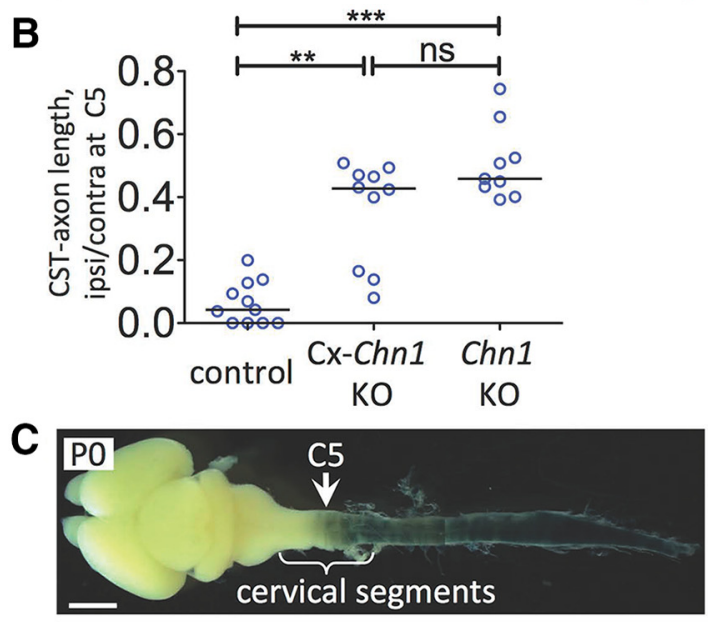

D
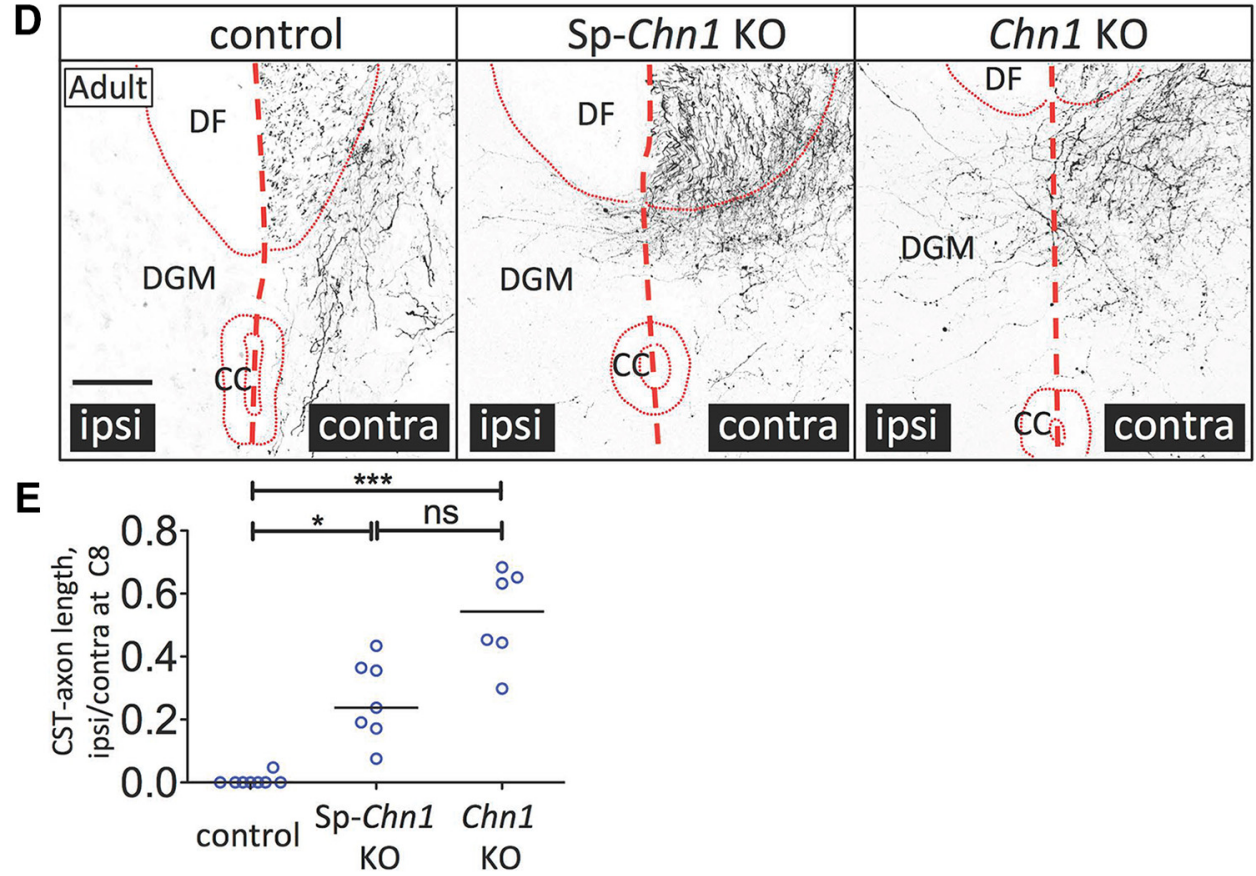

Figure 1. CST axons cross the spinal midline aberrantly in both cortex-specific and spinal-cord-specific $\alpha$-chimaerin-deficient mice. $\boldsymbol{A}$, BDA, an anterograde tracer, was unilaterally injected into the motor cortex (ipsilateral side) in adulthood and coronal sections taken at ( 5 were analyzed. Aberrant recrossing of BDA-labeled (ST axons at the DGM midline (thick dashed line) was frequently

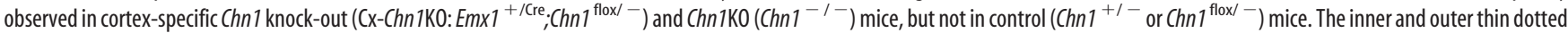
circles indicate the outline of the CC and ependymal cell layer surrounding the CC, respectively. $B$, Quantitative analysis of CST axon spinal midline crossing. The ratio of BDA-labeled CST axon length on the ipsilateral (ipsi) side to that on the contralateral (contra) side was significantly larger in C $\mathrm{x}$-Chn1KO mice $(n=10)$ and $C h n 1 \mathrm{KO}$ mice $(n=9)$ than those in control mice $(n=11)$ at $C 5$. There was no significant difference between $\mathrm{Cx}-\mathrm{Chn} 1 \mathrm{KO}$ and Chn1K0 mice. Data are presented as scatter plot and median; Kruskal-Wallis test; ${ }^{* *} p<0.01 ;{ }^{* * *} p<0.001$; ns, no significance. C, Whole-mount lacZ staining of Hoxb8-Cre;RNZ mice at P0 showed Cre-mediated recombination in the spinal segments caudal to $C 5$, but not in the cortex ( $n=3$ ). $\boldsymbol{D}$, BDA was injected unilaterally into the motor cortex in adulthood and coronal sections at C8, a caudal cervical segment, were analyzed. Aberrant recrossing of BDA-labeled CST axons at the DGM midline (thick dashed line) was

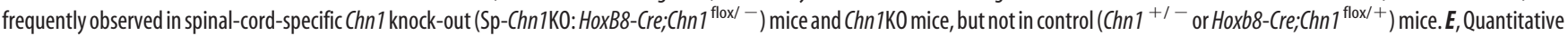
analysis of CST axon spinal midline crossing (for details, see Materials and Methods). The ratio of BDA-labeled axon length in the ipsilateral side to that in the contralateral side was significantly larger in Sp-Chn1 KO $(n=7)$ and Chn1 KO $(n=6)$ mice than in control mice $(n=8)$. There were no significant differences between Sp-Chn $1 \mathrm{KO}$ and Chn $1 \mathrm{KO}$ mice. Data are represented as scatter plot and median; Kruskal-Wallis test; ${ }^{*} p<0.05 ;{ }^{* * *} p<0.001 ; \mathrm{ns}$, no significance. Scale bars: $\boldsymbol{A}, \boldsymbol{D}, 50 \mu \mathrm{m} ; \boldsymbol{C}, 2 \mathrm{~mm}$. 
the cervical spinal cord such as C8 (Fig. 1D). The extent of aberrant midline crossing in Sp-Chn1KO and Chn1KO mice was significantly higher than that in control mice and no significant difference was observed between $\mathrm{Sp}-\mathrm{Chn} 1 \mathrm{KO}$ and Chn1KO mice (Kruskal-Wallis test: $p=0.0002$; Kruskal-Wallis statistic $=$ 17.42; Dunn's multiple-comparisons test: $p<0.01$, control vs Sp-Chn1KO; $p<0.001$, control vs Chn1KO; and ns, Sp-Chn1KO vs $C h n 1 \mathrm{KO}$; Fig. 1E). These results demonstrate that spinal-cellderived $\alpha$-chimaerin is also required to prevent aberrant midline crossing of CST axons.

\section{Spinal-cord-specific Chn1KO mice have breaks in the spinal MB (MB holes)}

Aberrant midline crossing of CST axons in the dorsal spinal cord of $\mathrm{Sp}-\mathrm{Chn} 1 \mathrm{KO}$ mice raised the possibility that the spinal MB in these mice may be dysfunctional. To test this possibility, we analyzed the midline morphology and found that the DF was smaller and the DGM was larger in the Sp-Chn1KO mouse spinal cord midline (Welch's $t$ test: $p=0.0056, t_{6}=4.216, R^{2}=0.75$; Fig. $2 A, B)$. The white matter DF contains sensory ascending and corticospinal descending axons and is located in the dorsomedial part of the spinal cord. The DGM is the area between the DF and CC. Similar morphological phenotypes have been reported in Chn1KO mouse midline (Iwasato et al., 2007).

Next, we examined ephrinB3 expression in the dorsal spinal midline in Sp-Chn1KO mice. The spinal MB uses ephrinB3 as a repulsive cue for the midline guidance of CST axons that express EphA4 (Coonan et al., 2001; Kullander et al., 2001a; Yokoyama et al., 2001). In P0 control mice, ephrinB3 was ubiquitously distributed throughout the dorsal midline in both the DF and DGM (Fig. 2C, left). In Sp-Chn1KO mice at the same age, ephrinB3 distribution patterns in the DF and ventral DGM (Fig. 2C, middle and right) were similar to those in control mice. However, in the dorsal DGM of Sp-Chn1KO mice, we found gaps in ephrinB3 distribution (Fig. $2 C$, right, arrow), which were never observed in control mice.

To analyze the ephrinB3 $(+) \mathrm{MB}$ in the dorsal spinal cord systematically, we prepared midsagittal sections at P0 (Fig. $3 A$ ) and stained them using an antibody for ephrinB3 (Fig. 3B). In control mice, ephrinB3 was uniformly distributed throughout the midline of the DF and DGM (Fig. 3B, top). EphrinB3(-) areas were observed only in the DF of control mice; however, these areas were occupied by blood vessels (Fig. 3B, top). Therefore, the ephrinB3 $(+) \mathrm{MB}$ was intact in the spinal cord of control mice. In the DF, the expression pattern of ephrinB3 in SpChn1KO mice was similar to that in control mice. In contrast, we found spindle-shaped ephrinB3(-) spaces (i.e., MB holes) that were not occupied by blood vessels in the dorsal part of the DGM midline of Sp-Chn1KO mice (Fig. $3 B$, bottom, $B^{\prime}$ ). The MB hole size was $31.9 \pm 19.6 \mu \mathrm{m}$ (mean $\pm \mathrm{SD}$; maximum: $88.9 \mu \mathrm{m}$, mininum: $6.0 \mu \mathrm{m}$ ) in the longitudinal axis and $9.4 \pm 5.9 \mu \mathrm{m}$ (mean $\pm \mathrm{SD}$; maximum: $28.9 \mu \mathrm{m}$, minimum: $2.6 \mu \mathrm{m}$ ) in the transverse axis in P0 Sp-Chn1KO mice $(n=42 \mathrm{MB}$ holes, two midsagittal sections, two mice; see Materials and Methods for details).

We also stained spinal midsagittal sections of Sp-Chn1KO mice using an antibody for nestin, an intermediate filament and MB marker (Hamilton et al., 2009; Sevc et al., 2009). In control mice, nestin $(+)$ radial processes of midline glia were arranged in parallel and the nestin signal overlapped with the ephrinB3 signal (Fig. 3C). In Sp-Chn1KO mice, nestin signals were well merged with ephrinB3 $(+)$ areas, but they were not detected in $\mathrm{MB}$ holes. Importantly, the longitudinal axes of MB holes paralleled
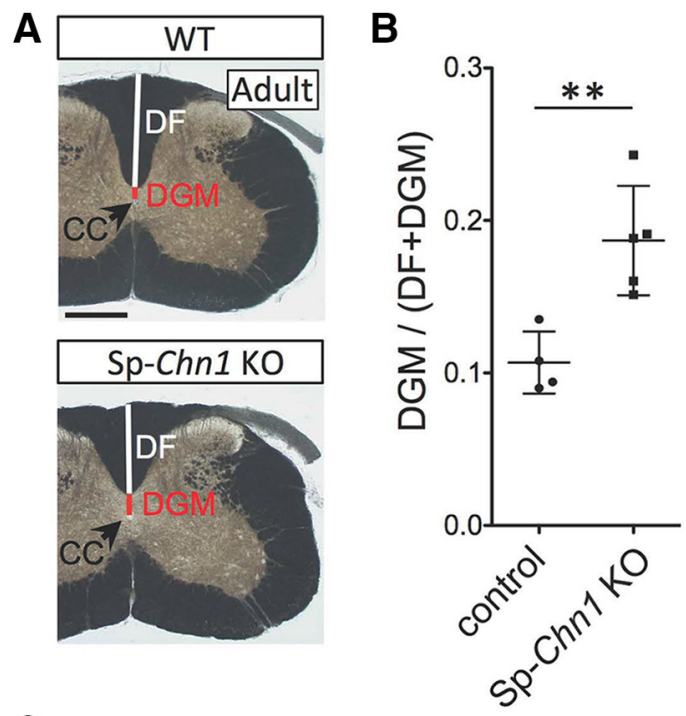

C

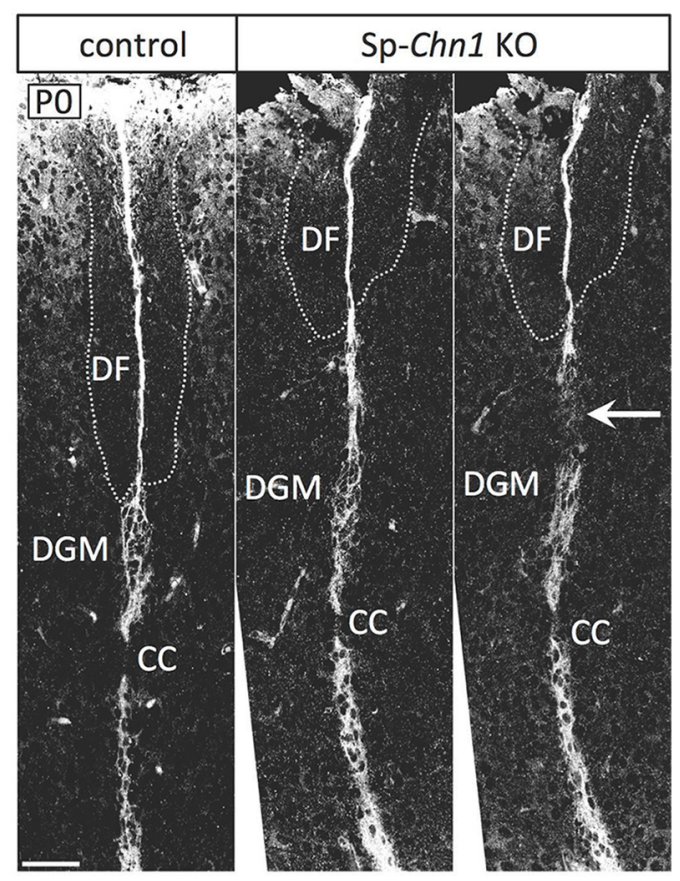

Figure 2. The MB is discontinuous in the absence of spinal $\alpha$-chimaerin. $\boldsymbol{A}$, In the midline the DF was smaller and the DGM was larger in Sp-Chn1KO (Hoxb8-Cre; Chn $1^{\text {flox/ - }}$ ) mice compared with those in control $\left(\mathrm{Chn} 1^{+/+}\right)$mice. Coronal sections at $\mathrm{C} 6$ in adulthood were shown. $\boldsymbol{B}$, Midline length of the DF and DGM (white and red lines, respectively, in $\boldsymbol{A}$ ) was quantified. The ratio of DGM to DF + DGM was significantly larger in Sp-Chn1K0 mice $(n=5)$ compared with control mice $(n=4)$. Mean \pm SD; Welch's $t$ test, ${ }^{* *} p<0.01$. C, Coronal sections of the cervical cord in control (Hoxb8-Cre; Chn $1^{\text {flox/+ }}$ ) and Sp-Chn 1KO (Hoxb8-Cre; Chn $1^{\text {flox/ }}$-) mice at P0 were stained with an anti-ephrinB3 antibody. In all control mouse sections analyzed ( $n=6$ sections from 3 mice), ephrinB3 was distributed continuously in the spinal midline in the DGM (left). In contrast, all Sp-Chn1KO mice had a section(s) that showed abnormal discontinuous ephrinB3 distribution (right, arrow), although some sections showed normal continuous distribution (middle) ( $n=6$ sections from 3 mice). Scale bars: $A, 500 \mu \mathrm{m} ; C, 50 \mu \mathrm{m}$.

nestin $(+)$ radial processes of midline glia and nestin $(+)$ processes adjacent to MB holes were continuous and not truncated (Fig. 3C). These results suggest that the $\mathrm{MB}$ hole was a space in which processes (and soma) of midline glia were absent rather than a space in which midline glia processes lost ephrinB3 expression.

We found MB holes in the dorsal DGM of the spinal cord of global Chn1KO mice (Fig. 3D), but not in Cx-Chn1KO mice (Fig. 


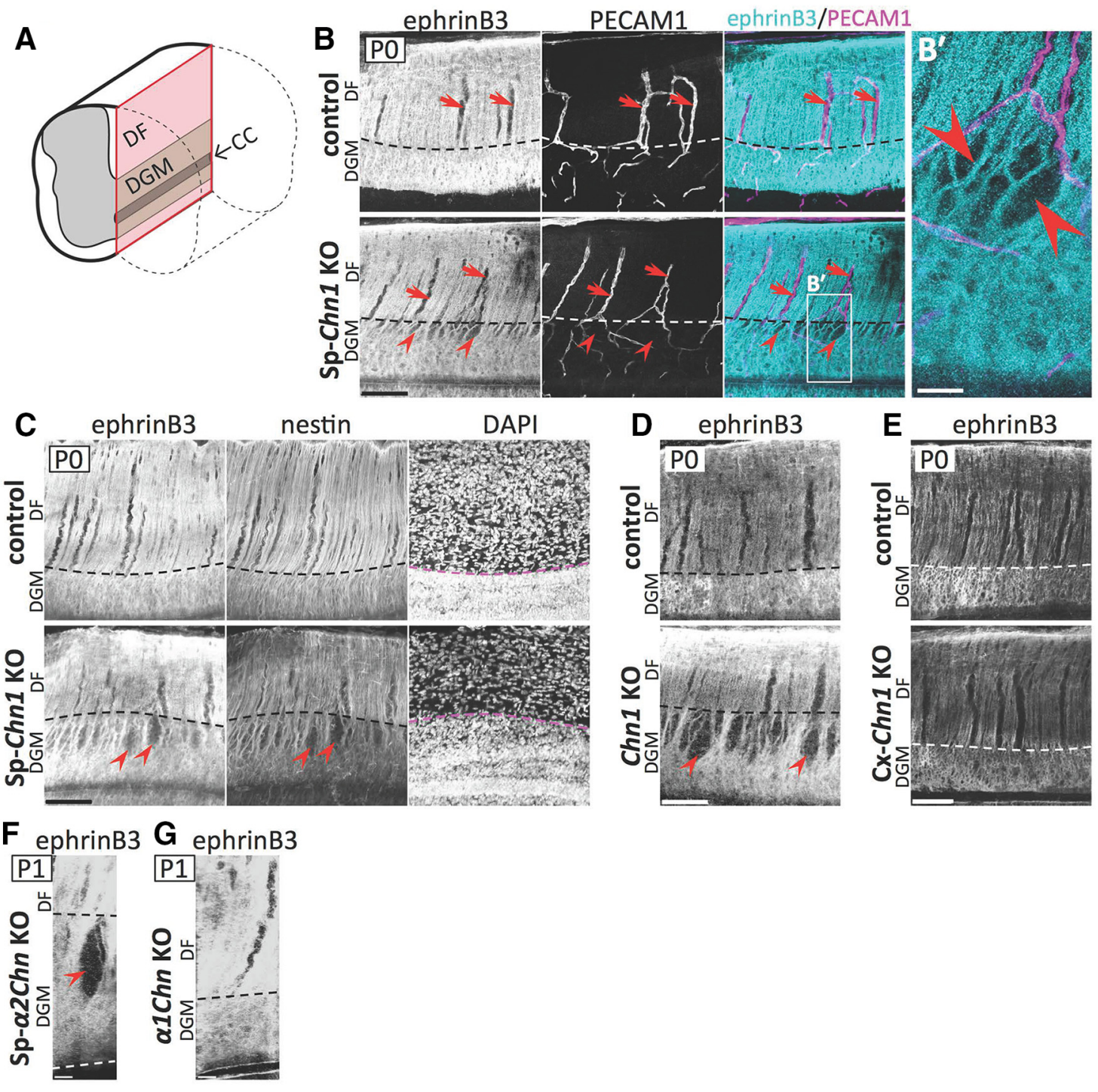

Figure 3. The spinal MB exhibits breaks (MB holes) in the absence of spinal $\alpha$-chimaerin. $\boldsymbol{A}$, Schematic diagram of midsagittal section of the spinal cord (red). $\boldsymbol{B}$, Midsagittal sections of the cervical cord in control (Hoxb8-Cre; Chn ${ }^{\text {flox/+ }}, n=2$ mice) and Sp-Chn1KO (Hoxb8-Cre; Chn ${ }^{\text {flox/ }}{ }^{-}, n=3$ mice) mice at PO were stained with antibodies for ephrinB3 and platelet endothelial cell adhesion molecule (PECAM1: a blood vessel marker). Both genotypes showed ephrinB3(-) areas that are filled with blood vessels (arrows) in the DF midline. In contrast, only Sp-Chn 1K0 mice exhibited spindle-shaped ephrinB3(-) areas (MB holes; arrowheads) in the dorsal part of the DGM MB. $\boldsymbol{B}^{\prime}$, High magnification of box in B. C, Midsagittal sections of the cervical cord in control (Chn $7^{\text {floxl }- \text {, }}$ $n=2$ mice) and Sp-Chn 1 KO (Hoxb8-Cre; Chn $1^{\text {flox } /-}, n=3$ mice) mice at PO were stained with antibodies for ephrinB3 and nestin (a midline glia marker), and DAPI (a nuclear marker). Control mice showed uniform distribution of ephrinB3 in the DGM midline. In contrast, Sp-Chn1K0 mice exhibited MB holes (arrowheads) in the dorsal part of the DGM and, in the ephrinB3(-) areas, nestin signal was also missing. The boundary between the DF and DGM was identified by density difference of DAPI(+) nuclei. $\boldsymbol{D}$, Chn 1 KO mouse ephrinB3(+) MB had holes (arrowheads). Midsagittal sections

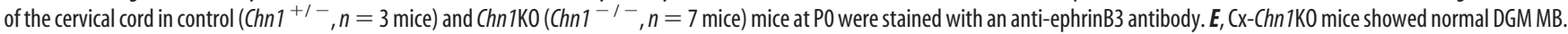

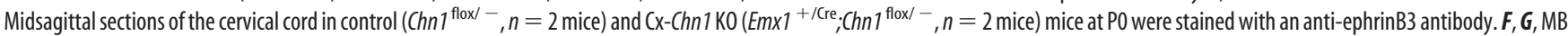
holes were found in the spinal cord midline of Sp- $\alpha 2 \mathrm{ChnKO}$ mice (arrowhead in $\boldsymbol{F}$ ) but not in that of $\alpha 1 \mathrm{ChnKO}$ mice (G). Coronal sections of the cervical cord in Sp- $\alpha 2 \mathrm{ChnKO}$ (Hoxb8-Cre; Chn $1^{\text {flox } \alpha 2 /-}, n=12$ sections from 3 mice) and $\alpha 1$ ChnKO mice (Chn1 ${ }^{\Delta \alpha 1 / \Delta \alpha 1}, n=12$ sections from 3 mice) at P1 were stained with an anti-ephrinB3 antibody. Pseudo-midsagittal sections were constructed from coronal $z$-stack images. Scale bars: $\boldsymbol{B}-\boldsymbol{E}, 100 \mu \mathrm{m} ; \boldsymbol{B}^{\prime}, 25 \mu \mathrm{m} ; \boldsymbol{F}, \boldsymbol{G}, 20 \mu \mathrm{m}$.

$3 E)$ at P0. $\alpha$-Chimaerin has two isoforms $(\alpha 1-$ and $\alpha 2$ chimaerin) (Dong et al., 1995). To examine the specific roles of each $\alpha$-chimaerin isoform in the MB phenotype, we prepared and examined $\alpha 1$-chimaerin knock-out $(\alpha 1 C h n K O)$ mice and spinal-cord-specific $\alpha 2$-chimaerin knock-out (Sp- $\alpha 2 C h n K O)$ mice. We observed that $\mathrm{Sp}-\alpha 2 \mathrm{ChnKO}$ mice had MB holes, but $\alpha 1 C h n K O$ mice did not (Fig. $3 F, G$ ), which was consistent with the fact that the $\alpha 2$ isoform is predominant in the embryonic spinal cord (Hall et al., 2001). These results clearly demonstrate that $\alpha$-chimaerin ( $\alpha 2$-chimaerin) is required in spinal cells to establish an intact DGM MB.
Corticospinal axons cross the spinal midline through $\mathrm{MB}$ holes in spinal-cord-specific Chn1KO mice

We examined the involvement of MB holes in aberrant midline crossing of CST axons in the spinal cord. We labeled unilateral CST axons with tdTomato (tdT) using in utero electroporation and visualized the $\mathrm{MB}$ using immunohistochemistry for nestin (Fig. 4A-C). We used P5 mice instead of P0 mice for these experiments because CST axons reach the spinal cord postnatally (Canty and Murphy, 2008). We obtained cervical coronal sections from Sp-Chn1KO mice and analyzed all of the tdT-labeled CST axons that crossed the DGM midline. In this analysis, we 

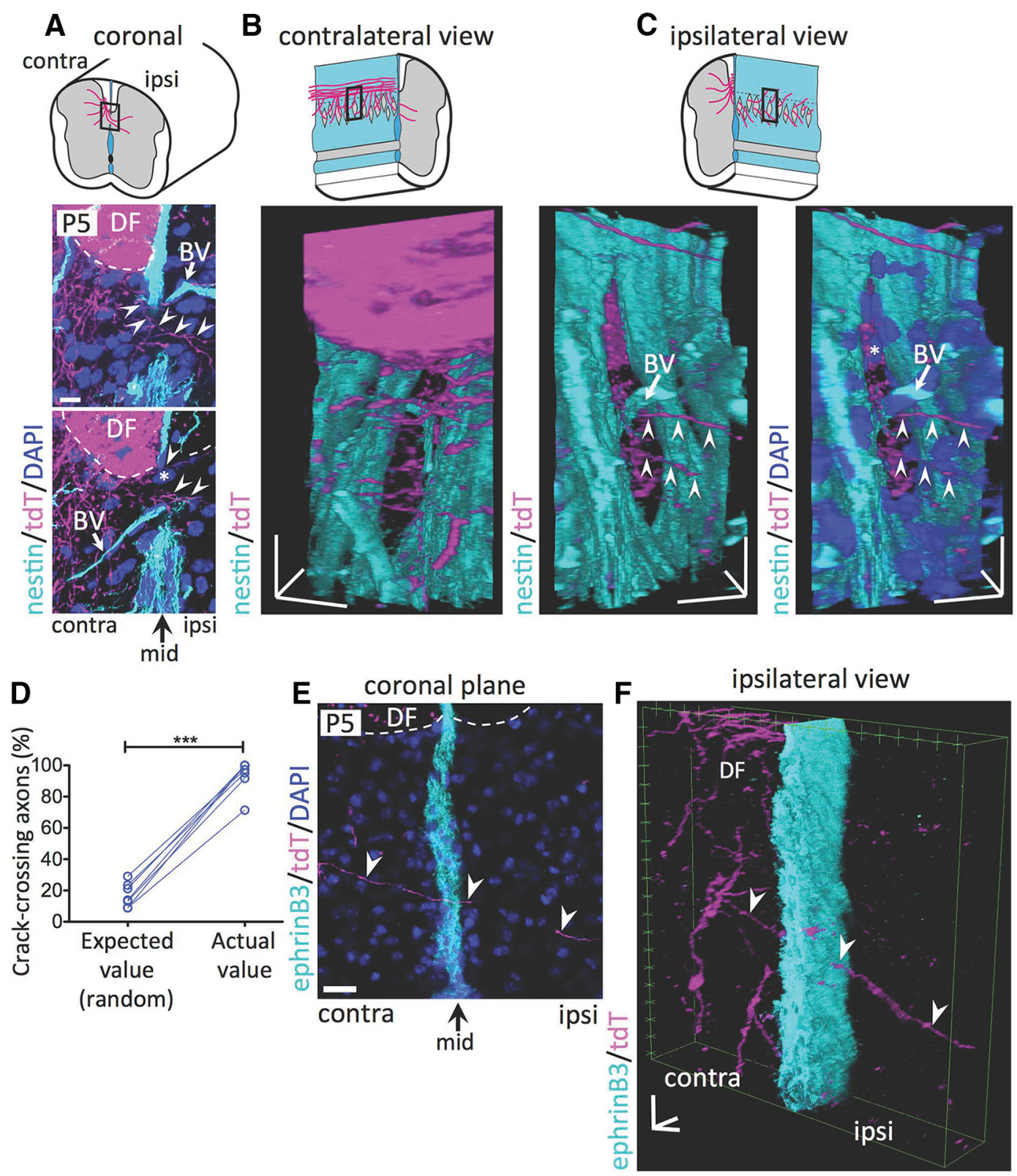

Figure 4. In Sp-Chn1KO mice, CST axons cross the spinal midline predominantly through MB holes. $\boldsymbol{A}-\boldsymbol{C}$, In the Sp-Chn 1KO (Hoxb8-Cre; Chn ${ }^{\text {flox/ }}{ }^{-}$) mouse spinal cord, CST axons (arrowheads) crossed the midline through MB holes [nestin $(-)$ space].z-projection images of coronal sections $(\boldsymbol{A})$ and contralateral $(\boldsymbol{B})$ and ipsilateral $(\boldsymbol{C})$ views in $3 \mathrm{D}$ construction are shown. In these images, an ephrinB3(-) cell (asterisk) and a blood vessel (BV) were observed in an MB hole, but several CST axons go through the space that is not filled with these cells. A tdT expression vector was introduced into the cortex of Sp-Chn $1 K 0$ mice by in utero electroporation at E13.5. Coronal sections of the lower cervical cord were made at P5 and stained with DAPI and an anti-nestin antibody. As reported previously (Mokry et al., 2008; Hamilton et al., 2009; Sevc et al., 2009), nestin staining detected not only midline glia, but also blood vessels. D, Actual value for the predominance of MB holes for aberrant CST axon midline crossing was calculated as the ratio of the number of MB hole-crossing tdT $(+)$ axons to the number of total tdT $(+)$ midline crossing axons. If CST axons cross the DGM midline randomly in an MB-hole-independent manner, then the ratio should be mostly equal to the value calculated as the ratio of the area of MB holes to the area of the DGM midline (MB area + MB hole area; $\boldsymbol{D})$. The actual value was significantly higher than the expected value. Seven sections from two Sp-Chn $1 K 0$ mice were used. Paired $t$ test, ${ }^{* * *} p<0.001 . E, F$, The midline $c^{*}$ ossing $C S T$ axons (arrows) passed through an intact MB [ephrinB3(+) areas] in Cx-Chn 1KO (Emx ${ }^{+/ \mathrm{Cre}} ;$ Chn $\left.{ }^{\text {flox/ }}{ }^{-}\right)$mice. The CST axons were labeled by introduction of tdT (magenta) by in utero electroporation in the cortex at $E 11.5$, and cervical sections were made at $\mathrm{P} 5$ and were stained with an anti-ephrinB3 antibody. $\boldsymbol{E}$, Single image of the coronal section. $\boldsymbol{F}$, Ipsilateral view in $3 \mathrm{D}$ construction. Scale bars: $\boldsymbol{A}-\boldsymbol{C}, 10 \mu \mathrm{m} ; \boldsymbol{E}, \boldsymbol{F}, 20 \mu \mathrm{m}$.

quantified 109 midline crossing axons. In almost all cases ( $\sim 95 \%, 104$ of 109 axons), aberrant midline crossing occurred through MB holes (Fig. $4 A-C)$. Only four ( $~ 5 \%)$ axons crossed the intact $\mathrm{MB}$ (data not shown). These results are conspicuous because MB holes occupied only a small portion of the DGM midline area. The ratio of $\mathrm{MB}$ hole-crossing axons was significantly higher than the ratio of the MB hole area to DGM midline area (ratio of $\mathrm{MB}$ hole-crossing axons: $93.7 \pm 10.3 \%$, mean \pm $\mathrm{SD}$; ratio of MB hole areas: $17.0 \pm 7.7 \% ; n=7$ sections from two mice; paired $t$ test: $p<0.0001, t_{(6)}=20.26, R^{2}=0.986$; Fig. $\left.4 D\right)$. These results indicate that CST axons predominantly crossed the spinal midline through MB holes in Sp-Chn1KO mice.

We next assessed how CST axons cross the spinal midline in $\mathrm{Cx}-\mathrm{Ch} n 1 \mathrm{KO}$ mice. Even though these mice showed aberrant midline crossing of CST axons in the spinal cord (Fig. 1A), they had a normal length DGM midline, as reported previously (Borgius et al., 2014), and had no MB holes in the spinal cord midline (Fig. 3E). CST axons labeled using in utero electroporation 

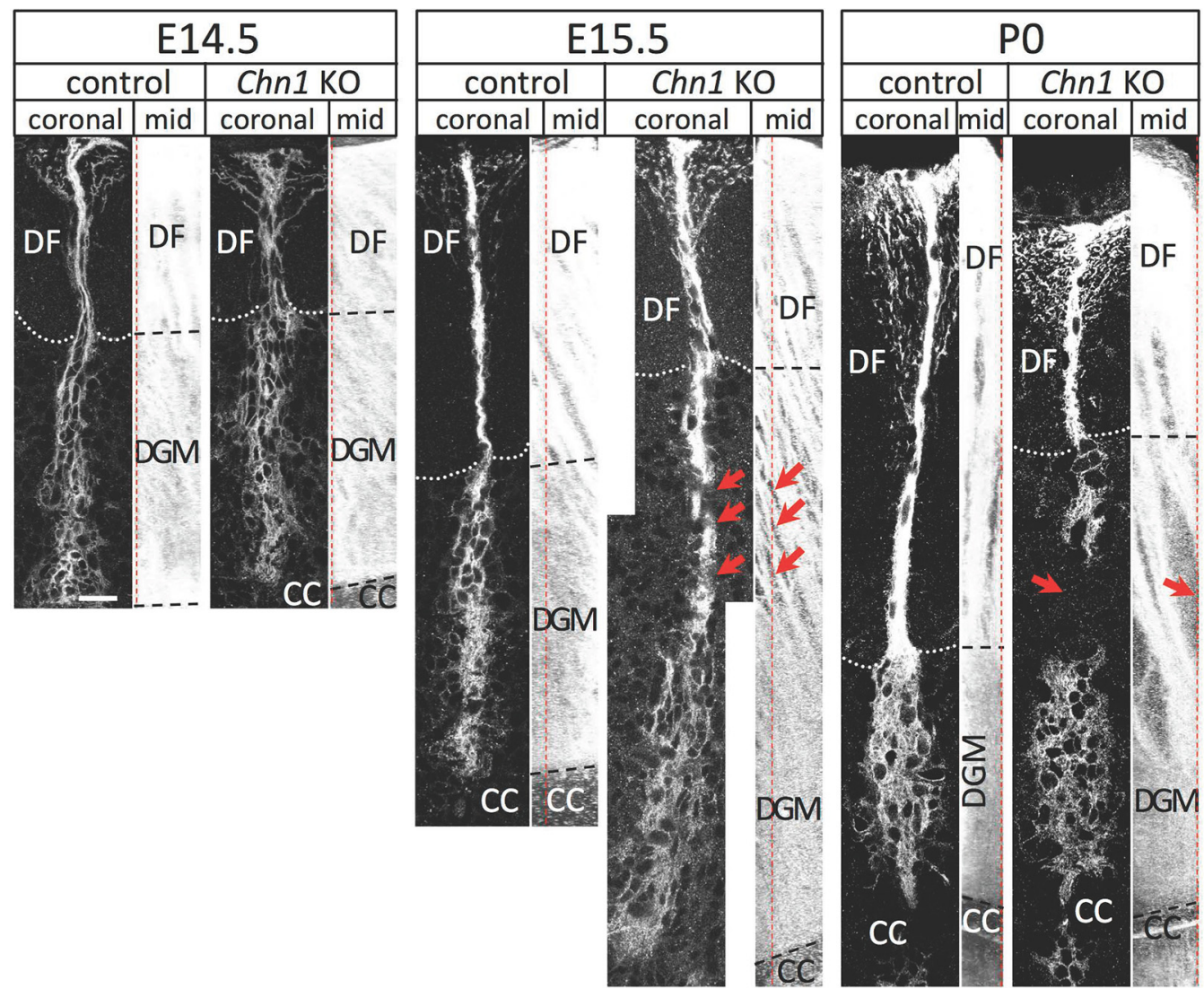

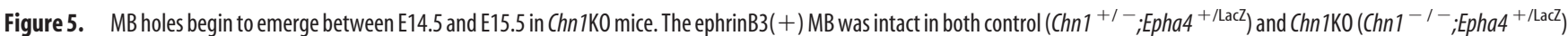
mice at E14.5. At E15.5 and P0, the MB was intact in control mice, whereas, in Chn1KO mice, holes (arrows) were found in the dorsal part of the DGM MB. Cervical coronal sections of control

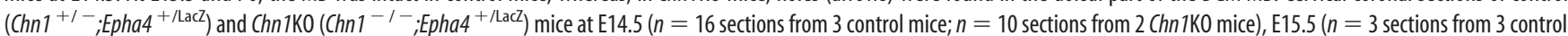
mice; $n=3$ sections from 3 Chn1KO mice), and PO ( $n=5$ sections from 2 control mice; $n=3$ sections from 3 Chn 1KO mice) were stained with an anti-ephrinB3 antibody. Coronal sections and pseudo-midsagittal sections that were constructed from z-stackimages (Mid) are shown. Red dashed lines in pseudo-midsagittal images indicate the z position of the corresponding coronal images. Scale bar, $20 \mu \mathrm{m}$.

crossed the midline through the intact DGM MB (Fig. 4E,F). These results indicate that the mechanisms allowing aberrant midline crossing of CST axons are distinct between $\mathrm{Cx}-\mathrm{Chn} 1 \mathrm{KO}$ and Sp-Chn1KO mice. In other words, cortical and spinal $\alpha$-chimaerin have distinct roles in blocking aberrant midline crossing. Cortical-neuron-derived $\alpha$-chimaerin is important for the repulsion of CST axons from the spinal MB, whereas spinalcell-derived $\alpha$-chimaerin establishes an intact spinal MB, which then inhibits aberrant midline crossing of CST axons.

Importantly, our light microscopy results suggest that aberrant midline crossing axons do not break the MB because we did not observe any $\mathrm{MB}$ holes around the midline crossing axons in Cx-Chn1KO mice ( $n=12$ axons; Fig. $4 E, F)$. Therefore, the presence of MB holes in Sp-Chn1KO mice is not a consequence of aberrant midline crossing of CST axons, but rather a cause.

\section{MB holes emerge during embryonic development in Chn1KO mice}

Next, we investigated when and how MB holes emerged during the development of Chn1KO mice. We labeled the spinal cord $\mathrm{MB}$ of Chn1KO and control embryos using an anti-ephrinnB3 antibody, analyzed the MB in the coronal plane using confocal microscopy and constructed a pseudo-midsagittal section using serial optical sections ( $0.5 \mu \mathrm{m} z$-spacing; Fig. 5). Similar to observations at $\mathrm{P} 0$, the $\mathrm{MB}$ of Chn1KO mice at E15.5 exhibited numerous MB holes (Fig. 5). The MB was intact in Chn1 KO mice at E14.5 (Fig. 5). At both ages, control mice had an intact MB. These results indicate that the formation of the MB in Chn $1 \mathrm{KO}$ mice appears normal, but begins to break between E14.5 and E15.5. Therefore, $\alpha$-chimaerin is required for the maintenance of the spinal $\mathrm{MB}$, but not for its formation.

EphA4 $(+)$ cells accumulate ectopically in spinal MB holes in Chn1KO mice

We have reported previously that $\alpha$-chimaerin binds to EphA4 and mediates ephrinB3-EphA4 repulsive signaling during motor circuit formation (Iwasato et al., 2007). It is likely that the ephrinB3-EphA4- $\alpha$-chimaerin signaling is also involved in the ephrinB3(+) MB phenotype of Chn1KO mice.

To explore this possibility, we analyzed $E f n b 3$ (ephrinB3 gene) and Epha4 (EphA4 gene) expression patterns in the developing spinal cord using in situ hybridization (Fig. 6A-F). In both genotypes, Efnb3-expressing cells were located in the dorsal and ventral midline and the majority of the dorsal group was translocated toward the ventral side after the shrinkage of primitive lumen during E13.5-E15.5 (Fig. 6A). At E14.5 or earlier, Epha4(+) cells were densely distributed in the vicinity of the midline (juxtamidline areas) of the dorsal spinal cord, but they were rarely detected within the midline in $\mathrm{Chn} 1 \mathrm{KO}$ and control mice (Fig. $6 A-C, F)$. At E14.5, there was no significant difference in the numbers of midline-located Epha4(+) cells between Chn1KO and control mice (Welch's $t$ test: $p=0.15, t_{(13)}=1.52, R^{2}=0.15$; 

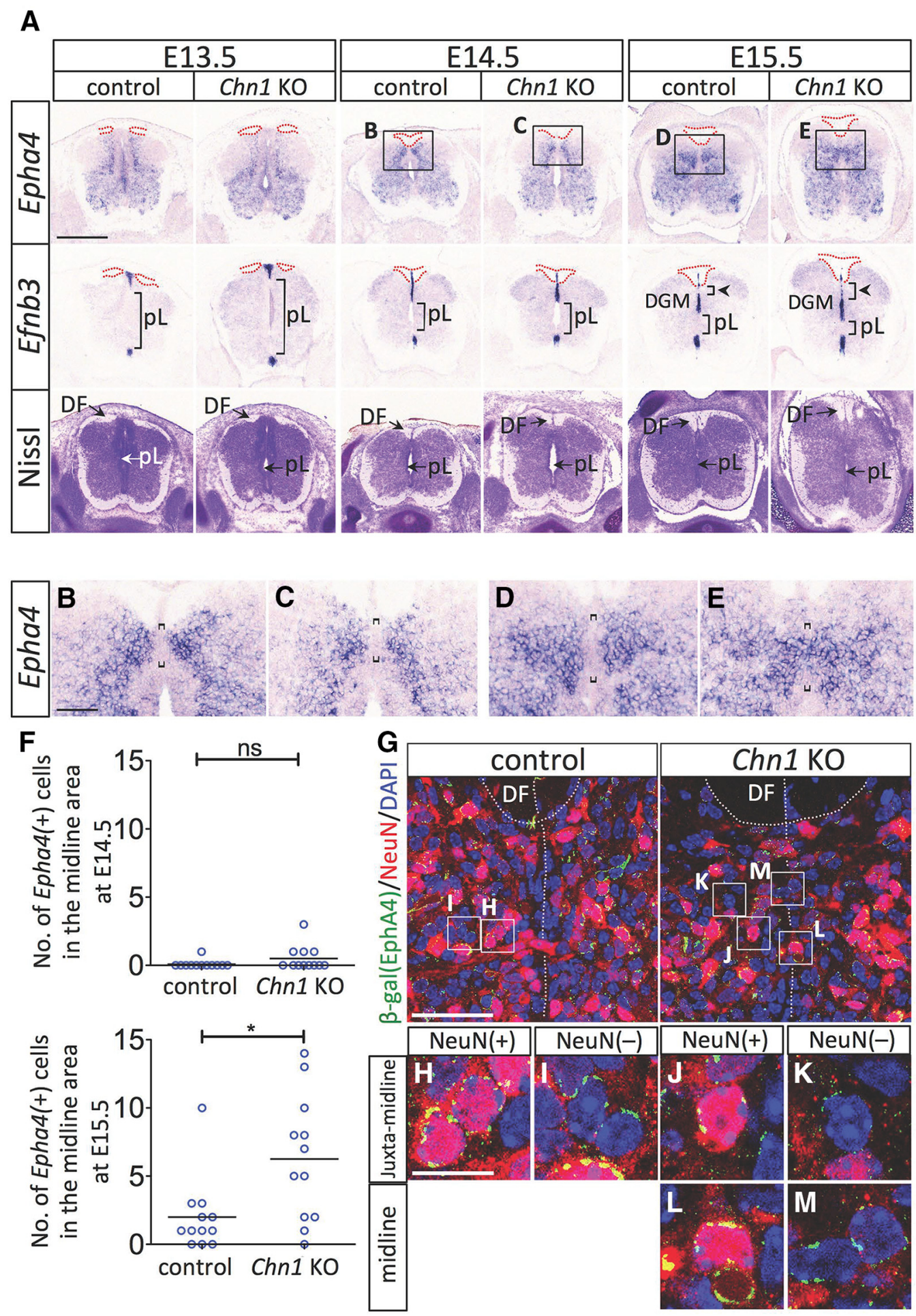

Figure 6. Distribution of EphA4(+) cells in developing Chn1 K0 mice. $\boldsymbol{A}-\boldsymbol{E}$, In the cervical cord of control (Chn $1^{+/-}$) and $\mathrm{Chn} 1 \mathrm{KO}$ (Chn $1^{-/-}$) mice at E13.5, E14.5, and E15.5, serial coronal sections were stained by cresyl violet (Nissl) and in situ hybridization probes for ephrinB3 and EphA4 genes (Efnb3 and Epha4, respectively). $A$, In control mice at E14.5 and E15.5, Epha4 ++ ) cells were located in midline-adjacent areas and excluded from the midline area $(\boldsymbol{B}, \boldsymbol{D})$. In Chn1K0 mice, Epha4(+) cells were normally excluded from the midline area at E14.5 (C), but at E15.5, some Epha4(+) cells were located ectopically in the midline area $(\boldsymbol{E})$. Brackets (width, $15 \mu \mathrm{m}$ ) in $\boldsymbol{B}-\boldsymbol{E}$ indicate the midline area. In both genotypes, Efnb3 was expressed in the dorsal and ventral midline during E13.5-E15.5 and the Efnb3 $(+)$ dorsal midline cells migrated ventrally after the gradual shrinkage of the primitive lumen $(\mathrm{pL} ; \boldsymbol{A})$. At E15.5, the gap [Efnb3 $(+)$ cell low-density area $(\boldsymbol{A}$, arrowheads)] located between the DF and the Efnb3 $(+)$ cell high-density area was larger in Chn 1 KO mice than that in control mice. $\boldsymbol{B}-\boldsymbol{E}$ are high magnification of boxes in $\boldsymbol{A} . \boldsymbol{F}$, Epha4 $(+)$ cells in the dorsal midline area (width: $15 \mu \mathrm{m}$ ) in sections ( $10 \mu \mathrm{m}$ thick) stained with in situ hybridization were counted. At E14.5, there was no significant difference in the number between control ( $n=12$ sections from 2 mice) and Chn 1KO mice ( $n=12$ sections from 2 mice). At E15.5, number of Epha4( + ) cells was significantly larger in Chn 1 K0 mice ( $n=12$ sections from 2 mice), compared with those in control mice $\left(n=12\right.$ sections from 2 mice). Welch's $t$ test, ${ }^{*} p<0.05$; ns, no significance. $\mathbf{G}-\mathbf{M}$, The majority of EphA4(+) cells in the spinal cord were neuronal. In control (Chn ${ }^{+/-} ;$;Epha4 $\left.{ }^{+/ \text {Lacz }}\right)$ and Chn 1KO (Chn1 ${ }^{-1-}$;Epha4 ${ }^{+/ \text {Lacz }}$ ) mice at E15.5, coronal sections in the cervical cord were stained with DAPl and antibodies for $\beta$-galactosidase and NeuN. In control mice, $71 \%$ of EphA4( + ) cells were NeuN-positive in the juxta-midline areas ( $100 \mu \mathrm{m}$ width centered on the midline) $[130 \mathrm{NeuN}(+) ; \beta$-gal $(+)$ cells $/ 183 \beta$-gal $(+)$ cells, $n=2$ sections from 2 mice $(\mathbf{G}-I)]$. In Chn $1 \mathrm{KO}$ mice, $66 \%$ and $82 \%$ of EphA4 $(+)$ cells were NeuN-positive in the midline [38 NeuN( + ); $\beta$-gal $(+)$ cells/58 $\beta$-gal $(+)$ cells, $n=4$ sections from 2 mice] and juxta-midline areas $[287$ NeuN $(+) ; \beta$-gal( + ) cells $/ 348 \beta$-gal( + ) cells, $n=2$ sections from 2 mice], respectively $(\boldsymbol{G}, \boldsymbol{J}-\boldsymbol{M})$. Scale bars: $\boldsymbol{A}, 500 \mu \mathrm{m} ; \boldsymbol{B}-\boldsymbol{E}, 100 \mu \mathrm{m} ; \boldsymbol{G}, 40 \mu \mathrm{m} ; \boldsymbol{H}-\boldsymbol{M}, 10 \mu \mathrm{m}$. 
Fig. 6F). In control mice aged E15.5 or later, Epha4(+) cells were densely distributed in the juxta-midline areas, but they were excluded from the midline itself (Fig. 6A, D,F, and data not shown), as reported previously (Escalante et al., 2013; Paixão et al., 2013). In contrast, in Chn1KO mice at the same age, Epha4 $(+)$ cells were distributed in both the juxta-midline areas and within the midline (Fig. $6 A, E, F$ ). At E15.5, there were significantly more midline Epha4(+) cells in Chn1KO mice than in control mice (Welch's $t$ test: $p=0.014, t_{(17)}=2.75, R^{2}=0.31$; Fig. $6 F$ ). Therefore, in the absence of $\alpha$-chimaerin, Epha4 $(+)$ cells accumulate aberrantly in the midline between E14.5 and E15.5.

To examine the cell type in juxta-midline and mislocated midline EphA4 $(+)$ cells, we performed immunostaining for NeuN, a neuronal marker (Fig. 6G-M). To label EphA4(+) cells, we used Epha4-LacZ (Epha4 $\left.{ }^{+/ L a c Z}\right)$ mice (Leighton et al., 2001). In these mice, the $\beta$-gal gene is expressed under the control of the endogenous Epha4 promoter. Therefore, EphA4 $(+)$ cells can be identified using the $\beta$-gal signal localized in perinuclear regions. In control mice (Fig. $6 G$, left), we found both neurons $[\mathrm{NeuN}(+)$, Fig. $6 \mathrm{H}]$ and non-neuronal cells $[\mathrm{NeuN}(-)$, Fig. $6 I]$ among juxta-midline EphA4 $(+)[\beta-\operatorname{gal}(+)]$ cells, the majority of which were neurons [ $71 \%$ ( 130 of 183 cells)]. In Chn1KO mice (Fig. 6G, right), we found both neurons and non-neuronal cells among juxta-midline and mislocalized midline EphA4 $(+)$ cells (Fig. 6J$M)$. Again, the majority of juxta-midline and midline EphA4(+) cells $(82 \%, 287$ of 348 cells, and $66 \%, 38$ of 58 cells, respectively) were neurons.

To analyze the relationship between the ectopic midline distribution of EphA4 $(+)$ cells and the position of MB holes in the Chn1KO mouse spinal cord, we simultaneously labeled EphA4(+) cells and the MB using immunohistochemistry (Fig. 7). To label EphA4(+) cells, we used Epha4 ${ }^{+/ \text {LacZ }}$ mice. We analyzed mice at E15.5, when MB holes emerge in mutants. Several EphA4 $(+)$ cells were located in MB holes in Chn1KO (Epha4 ${ }^{+/ \mathrm{LacZ}} ; \mathrm{Chn1}^{-1-}$ ) mice (Fig. 7A-G). The ratio of EphA4 $(+)$ cells in MB holes to the total EphA4 $(+)$ cells in the DGM midline ( $\mathrm{MB}+\mathrm{MB}$ hole) was significantly higher than the expected ratio based on the calculated ratio of $M B$ hole area to the total DGM midline area (paired $t$ test: $p=0.0002, t_{(4)}=12.83, R^{2}=$ 0.976; Fig. 7H). Therefore, aberrant midline EphA4(+) cells accumulated preferentially in $\mathrm{MB}$ holes in $\mathrm{Chn} 1 \mathrm{KO}$ mice.

\section{EphA4-repulsive signaling prevents EphA4 cells from invading the spinal $\mathrm{MB}$}

The aberrant midline accumulation of EphA4 $(+)$ cells in Chn1KO mice raised the possibility that the ephrinB3-expressing MB prevents the invasion of juxta-midline EphA4(+) cells using an ephrinB3-EphA4 repulsive signal and that $\alpha$-chimaerin mediates this repulsive cell signal as a key downstream effector of EphA4. If this is the case, then Epha4 mutant mice may show MB phenotypes similar to those of Chn1 mutant mice. Indeed, Epha4 mutant mice share many phenotypes with $C h n 1$ mutant mice. Both global and spinal-cord-specific Epha4KO mice (Epha4KO and Sp-Epha4KO mice, respectively) show shrinkage of the DF and aberrant midline crossing of CST axons (Kullander et al., 2001a; Paixão et al., 2013). Furthermore, EphA4 promoter-active (EphA4) cells accumulate aberrantly in the spinal cord midline of Epha4KO and Sp-Epha4KO mice (Restrepo et al., 2011; Paixão et al., 2013). Here, we investigated whether Epha4KO mice have MB holes in the spinal MB and, if so, if ectopic midline EphA4 cells are located within MB holes. For this purpose, we used homozygous Epha4-LacZ (Epha4 $4^{\text {LacZ/LacZ) }}$ mice (Leighton et al., 2001). The spinal midline of Epha4KO mice had MB holes similar to those of Chn1KO mice (Fig. $8 A-G$ ). We found many mislocalized EphA4 $[\beta$-gal $(+)]$ cells in these MB holes (Fig. $8 A-G$ ). The ratio of the number of EphA4 cells in MB holes to the total number of EphA4 cells in the DGM midline area was significantly higher than the expected ratio based on the calculated ratio of $\mathrm{MB}$ hole area to the total DGM midline area (paired $t$ test: $p=$ $0.0001, t_{(4)}=14.65, R^{2}=0.982$; Fig. $8 H$ ).

If $\alpha$-chimaerin functions as a key downstream effector of EphA4 cell repulsion, then this protein should be expressed in repulsed EphA4 cells. To test this hypothesis, we analyzed E15.5 Epha $4^{+/ \text {LacZ }}$ mice using double immunohistochemistry for $\beta$-gal and $\alpha 2$-chimaerin (Fig. $9 A-G$ ). As expected, $\alpha 2$ chimaerin was expressed in the majority of juxta-midline EphA4 cells (Fig. 9A,D). We also examined $\alpha 2$-chimaerin expression in Epha4 ${ }^{\text {LacZ/LacZ }}$ mice. EphA4 cells located in the juxta-midline areas and those located in the midline expressed $\alpha 2$-chimaerin (Fig. 9B,F).

To test directly the possibility that EphA4 cells translocate to the midline in the absence of EphA4 function, we unilaterally labeled the spinal cells of Epha4 ${ }^{\text {+LacZ }}$ and Epha $4^{\text {LacZ/LacZ mice. }}$ We introduced a GFP expression vector unilaterally into the spinal cord at E11.5 using in utero electroporation and analyzed the tissue at E17.5 (Fig. 10). EphA4 cells were identified by the presence of a $\beta$-gal signal. We found that a few GFP-labeled nonEphA4 $[\beta$-gal $(-)]$ cells were distributed in the ipsilateral spinal cord, midline area, and contralateral side in both genotypes (Fig. $10 A-D)$. Some of these cells appeared to be midline radial glia (Fig. $10 F, K$ ) because they were located in the midline and extended their processes along the DV axis (Fig. $10 F^{\prime}, K^{\prime}$, arrows). Other cells (Fig. 10G, $H, L, M$ ) that extended their processes orthogonally to the DV axis (Fig. $10 G^{\prime}, H^{\prime}, L^{\prime}, M^{\prime}$, arrows) were likely dorsal commissural neurons (Orlino et al., 2000; Comer et al., 2015).

Importantly, GFP-labeled EphA4 $[\beta-\operatorname{gal}(+)]$ cells were not found in the midline and on the contralateral side of the spinal cord in control mice (Fig. 10 A, B, R,S). In contrast, GFP-labeled EphA4 cells were often distributed in the midline and on the contralateral side of the spinal cord in Epha4KO mice (Fig. $10 C, D, O-S)$. The ratio of midline GFP-labeled EphA4 cells to total GFP-labeled EphA4 cells in Epha4KO mice was significantly higher than that in control mice (Mann-Whitney $U$ test: $p=$ $0.0078, U=17.5$; Fig. $10 R$ ) and the ratio of contralateral GFPlabeled EphA4 cells to total GFP-labeled EphA4 cells in Epha4KO mice was also significantly higher than that in control mice (Mann-Whitney $U$ test: $p=0.0078, U=17.5$; Fig. 10S). In addition, GFP-labeled EphA4 cells projecting axon-like thin processes to the ipsilateral side were found frequently on the contralateral side (Fig. $10 P^{\prime}, Q^{\prime}$, arrows). These results strongly support our hypothesis that the ephrinB3-expressing MB prevents the invasion of juxta-midline EphA4 cells that express $\alpha 2$ chimaerin via an ephrinB3-EphA4- $\alpha 2$-chimaerin cell-repulsive signaling pathway.

\section{Discussion}

We have shown that in Sp-Chn1KO (and Sp- $\alpha 2 C h n K O$ and Chn1KO) mice, the dorsal spinal MB has breaks (MB holes), and CST axons aberrantly cross the midline through MB holes. In the absence of $\alpha$-chimaerin, juxta-midline EphA4 cells aberrantly translocate to the midline between E14.5 and E15.5, while the MB simultaneously forms MB holes around these cells. In Epha4KO mice, the spinal midline also has MB holes in which EphA4 cells are located. We propose that spinal $\alpha$-chimaerin ( $\alpha 2$-chimaerin) plays a critical role in the establishment of an intact $\mathrm{MB}$ by 
A

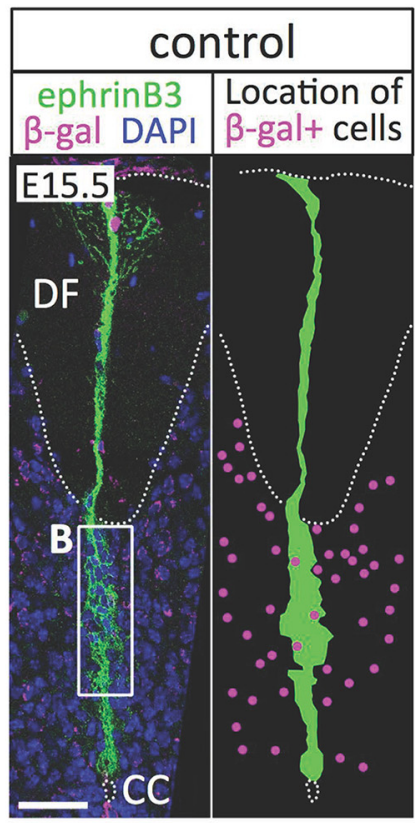

C

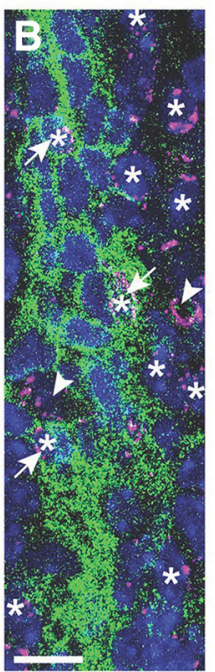

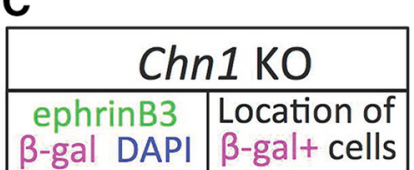
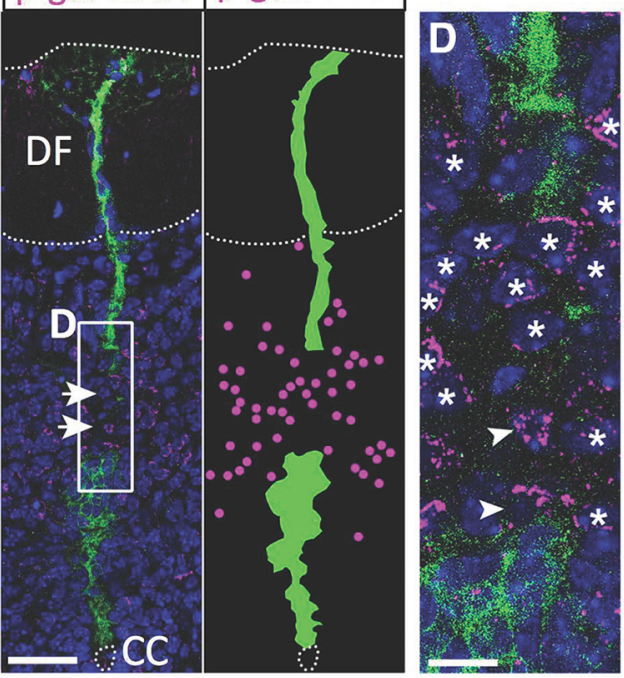

E

$\mathbf{F}$ coronal D-V reslicing

G mid-
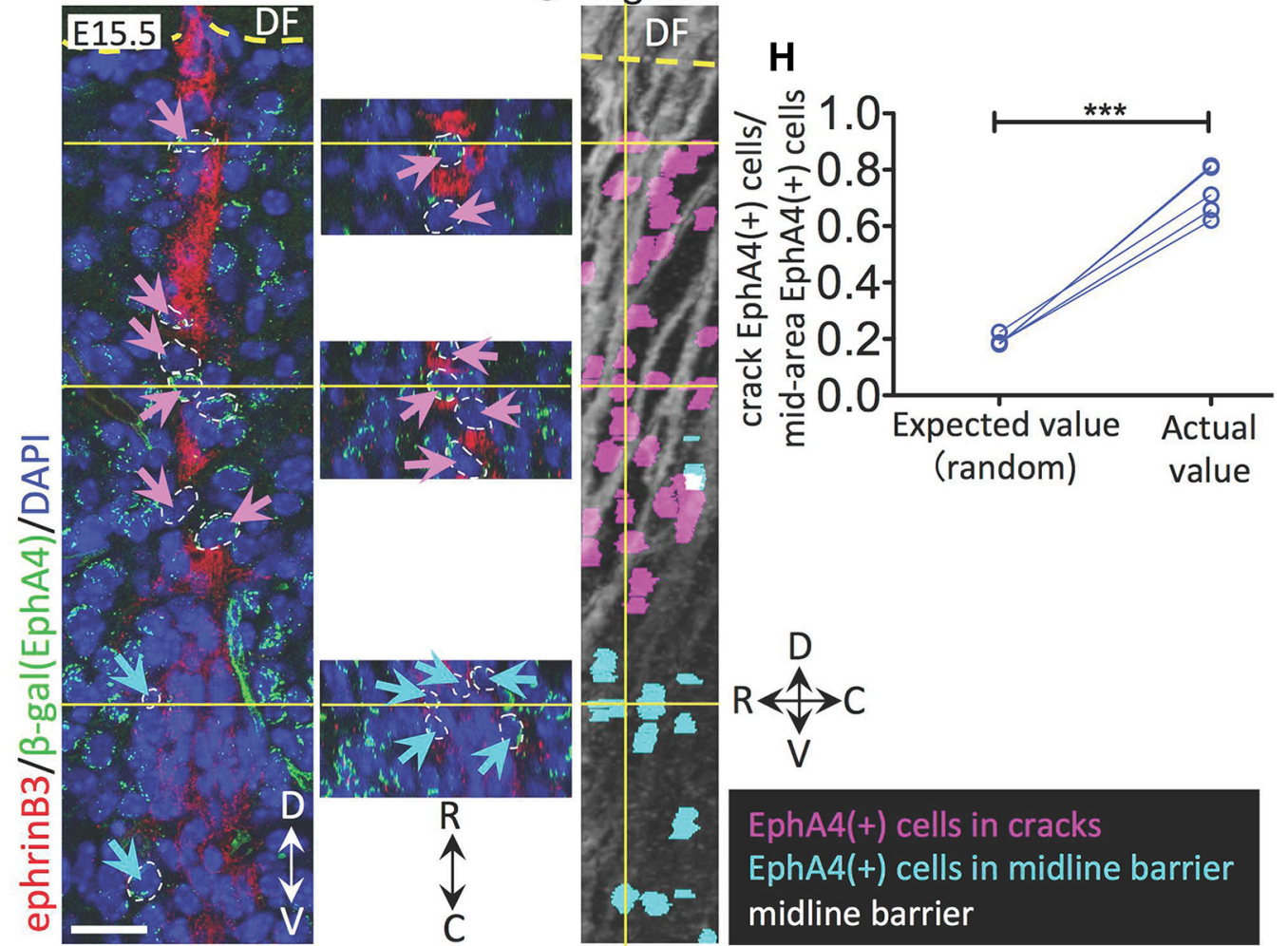<smiles>[R]C12C3C1C32C</smiles>

EphA4(+) cells in cracks EphA4(+) cells in midline barrier midline barrier

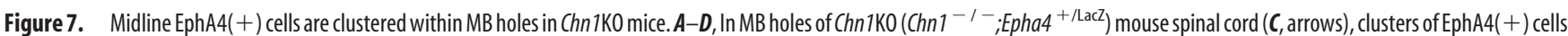
were observed $(\boldsymbol{C}, \boldsymbol{D})$. In control $\left(\mathrm{Chn1^{+/- }} ;\right.$;Epha4 $\left.{ }^{+/ \text {LacZ }}\right)$ mice $(\boldsymbol{A})$, a few EphA4(+) cells were observed within the ephrinB3 $(+) \mathrm{MB}(\boldsymbol{B}$, arrows), but these cells were not clustered and no holes were observed around these cells. Right panels in $\boldsymbol{A}$ and $\boldsymbol{C}$ are from the left panels in $\boldsymbol{A}$ and $\boldsymbol{C}$, respectively, and indicate the location of $\beta$-gal $(+)$ cells (magenta) and the MB (green). In this set of experiments, EphA4(+) cells (asterisks) were detected using the anti- $\beta$-gal antibody staining in the Epha4-LacZ mouse line. Cervical coronal sections (100 $\mu \mathrm{m}$ thick) at E15.5 were stained using anti- $\beta$-gal and anti-ephrinB3 antibodies and DAPI. The anti- $\beta$-gal antibody also detected blood vessels (arrowheads in $\boldsymbol{B}$ and $\boldsymbol{D}$ ). $\boldsymbol{B}$ and $\boldsymbol{D}$ are high magnification of the boxes in $\boldsymbol{A}$ and $\boldsymbol{C}$, respectively. $\boldsymbol{E}-\mathbf{G}, \operatorname{In} \mathrm{Chn}^{-1-} ;$ Epha4 ${ }^{+/ \text {LacZ }}$ mouse spinal cord, the majority of EphA4(+) $[\beta$-gal( $(+)]$ cells located in the midline (surrounded by white dashed line) were observed in MB holes (magenta arrows), although some were also observed within the MB (cyan arrows). Cervical coronal sections (100 $\mu \mathrm{m}$ thick) at E15.5 were stained using anti-ephrinB3 and anti- $\beta$-gal antibodies and DAPI. We determined whether individual cells located in the midline were EphA4(+) and if individual midline EphA4(+) cells are located in MB holes (magenta) or within the MB (cyan) by analyzing 3D images. $\boldsymbol{E}-\boldsymbol{G}$ are coronal and DV reslicing sections and midsagittal images, respectively. Horizontal yellow solid lines in $\boldsymbol{E}$ correspond to those in $\boldsymbol{F}$ and $\boldsymbol{G}$. The position of $\boldsymbol{E}$ is indicated as a vertical yellow line in G. D, Dorsal; $V$, ventral; $R$, rostral; $C$, caudal. $\boldsymbol{H}$, Quantitative analysis indicating that actual value [ratio of number of EphA4(+) cells in MB holes to number of EphA4( + ) cells in DGM midline area] was significantly higher than expected value that was calculated from ratio of MB hole area to DGM midline area (MB area $+M B$ hole area). Five sections from three Chn $1 K 0$ mice were analyzed. Paired $t$ test, ${ }^{* * *} p<0.001$. Scale bars: $A, C, 40 \mu \mathrm{m} ; \boldsymbol{B}, \mathbf{D}, 10 \mu \mathrm{m} ; \boldsymbol{E}-\mathbf{G}, 20 \mu \mathrm{m}$. 
A

\begin{tabular}{|c|c|}
\hline \multicolumn{2}{|c|}{ control } \\
\hline ephrinB3 & Location of \\
B-gal DAPI & $\beta$-gal+ cells \\
\hline
\end{tabular}

\section{PO}

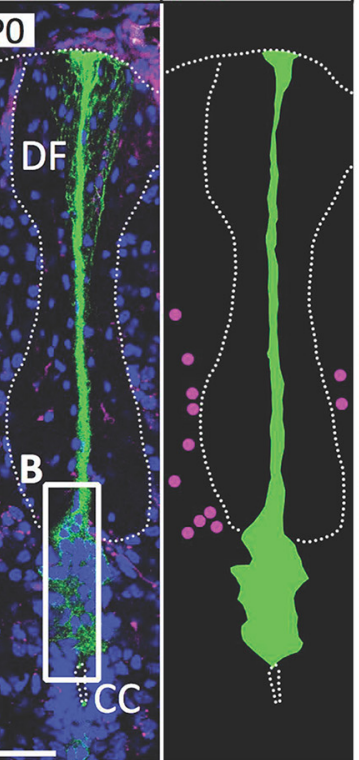

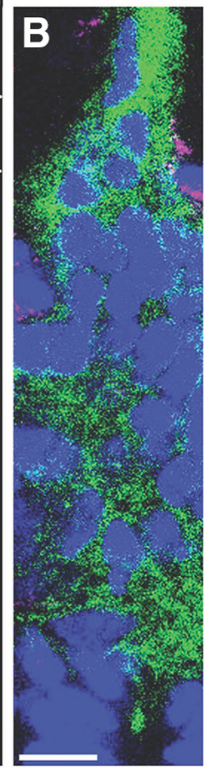

G

\section{E}
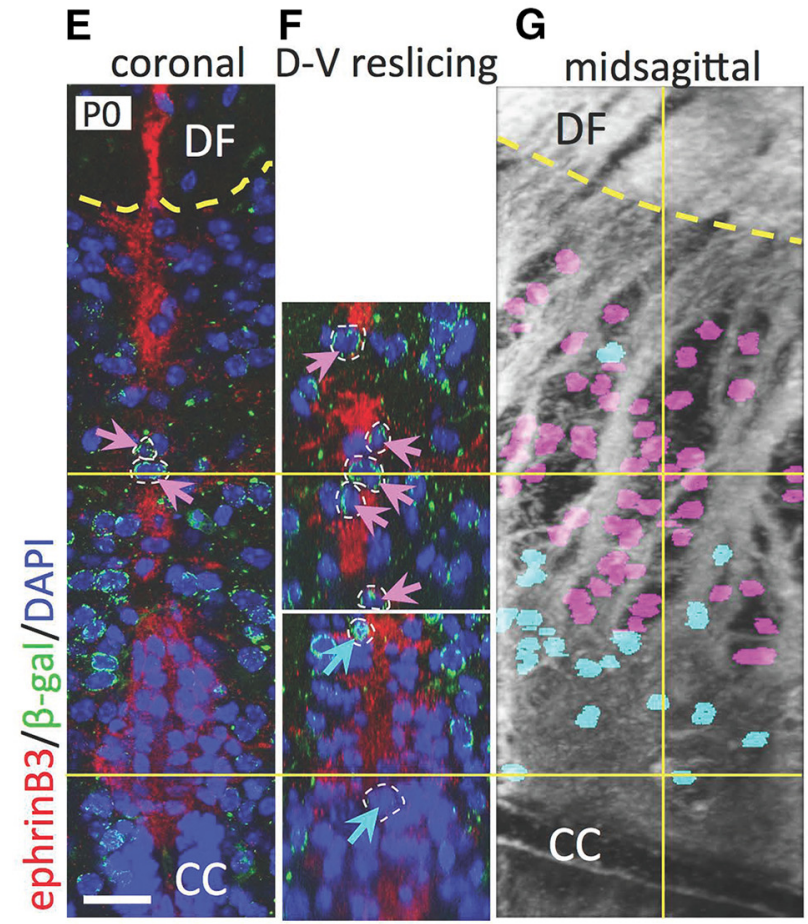

C
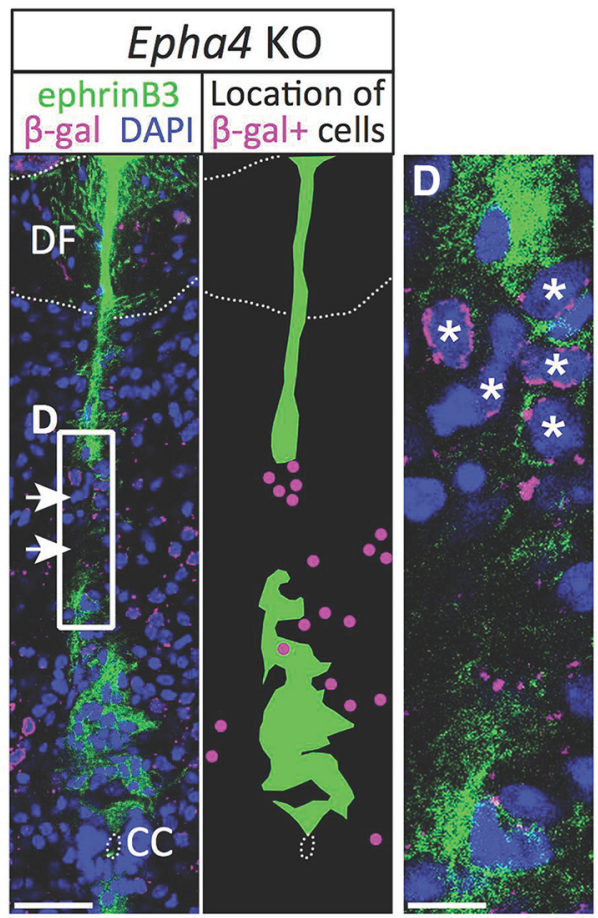

H
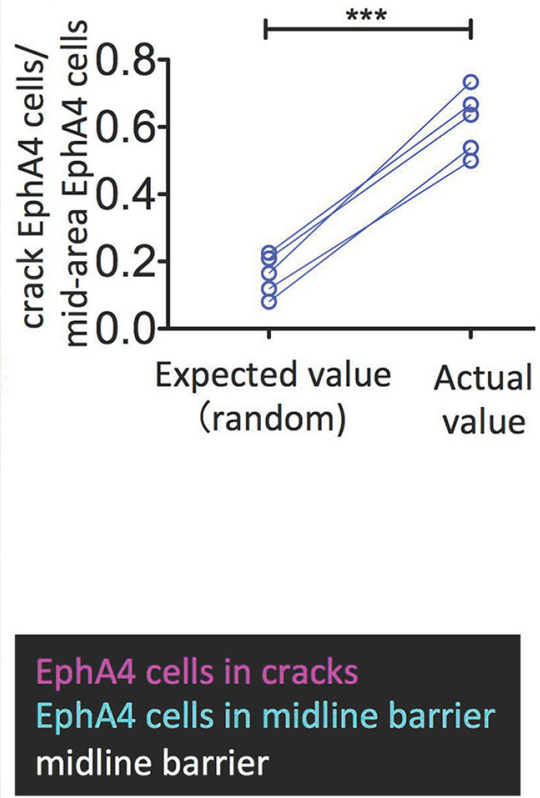

Figure 8. Ectopic midline-EphA4 cells are clustered within MB holes in Epha4K0 mice. $\boldsymbol{A}-\boldsymbol{D}$, Epha4K0 mice showed holes in the ephrinB3(+) MB (C, arrows). In the holes, ectopic EphA4 cells $[\beta$-gal( + ) cells; asterisks] were clustered (D). Right panels in $\boldsymbol{A}$ and $\boldsymbol{C}$ are depicted on the basis of the left panels in $\boldsymbol{A}$ and $\boldsymbol{C}$, respectively, and indicate the location of $\beta$-gal ( + ) cells (magenta) and the MB (green). Cervical coronal sections (100 $\mu \mathrm{m}$ thick) in control (Epha4 ${ }^{+/ L a c Z}$ ) and Epha4KO (Epha4 ${ }^{\text {LacZ/Lacz) }}$ ) mice at P0 were stained with DAPI and anti-ephrinB3 and anti- $\beta$-gal antibodies $(\boldsymbol{A}-\boldsymbol{D})$. $\boldsymbol{B}$ and $\boldsymbol{D}$ are high magnification of boxes in $\boldsymbol{A}$ and $\boldsymbol{C}$, respectively. $\boldsymbol{E}-\boldsymbol{G}$, In the Epha4KO mouse spinal cord $(\boldsymbol{E}, \boldsymbol{F})$, the majority of EphA4 cells located in the midline (surrounded by white dashed line) were found in MB holes (magenta arrows), although some were found within the MB (cyan arrows). In a midsagittal section (G), distribution of EphA4 cells in MB holes (magenta) and that of EphA4 cells in MB (cyan) were plotted. Cervical coronal sections (100 $\mu \mathrm{m}$ thick) at P0 Epha4KO mice were stained with anti-ephrinB3 and anti- $\beta$-gal antibodies and DAPI. Yellow lines in the coronal section $(\boldsymbol{E})$ correspond to those in DV reslicing sections $(\boldsymbol{F})$. Vertical and horizontal yellow solid lines in $\boldsymbol{G}$ indicate the position of cross-sections in $\boldsymbol{E}$ and $\boldsymbol{F}$, respectively. $\boldsymbol{H}$, Quantitative analysis indicated that actual value [ratio of number of EphA4 cells in MB holes to number of EphA4 cells in DGM midline area] was significantly higher than expected value that was calculated from ratio of DGM MB hole area to DGM midline area. Five sections from five Epha4KO mice were analyzed. Paired $t$ test, ${ }^{* * *} p<0.001$. 


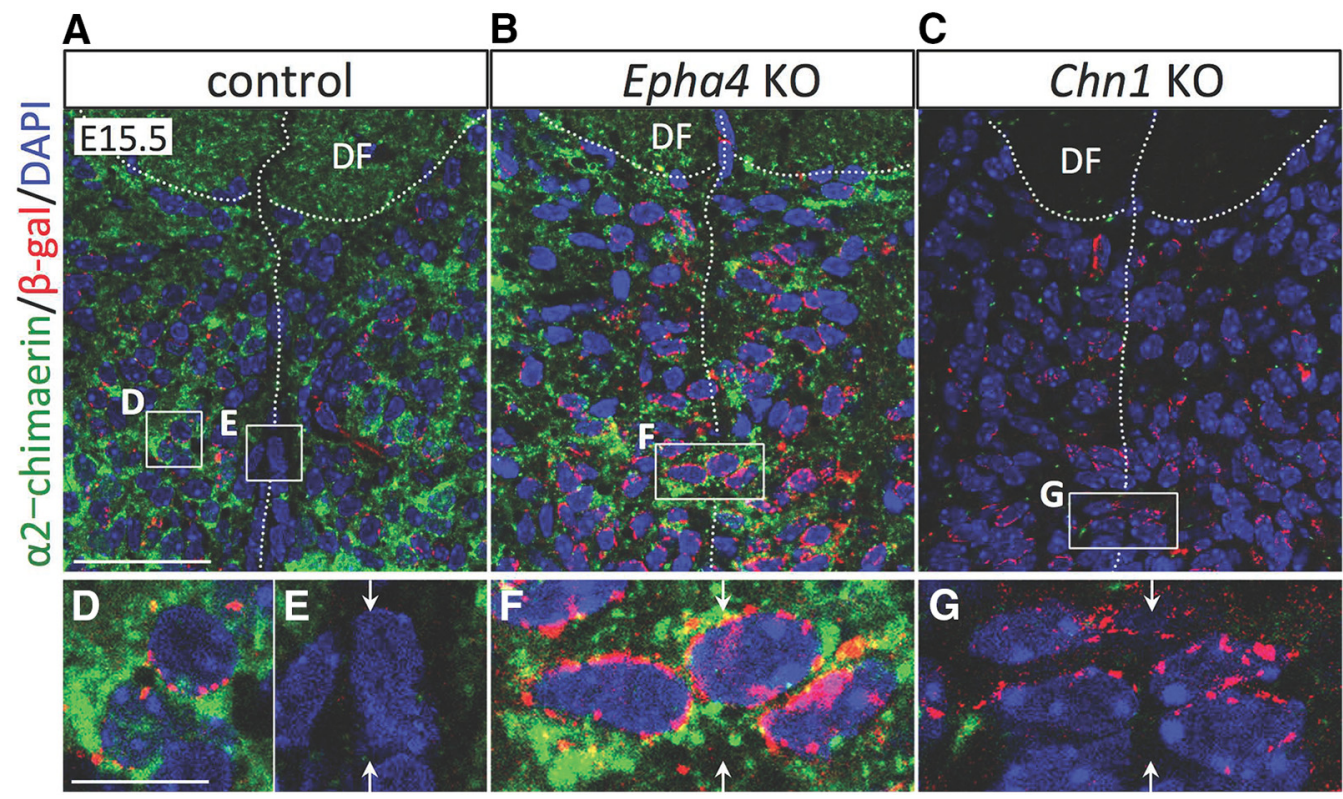

Figure 9. EphA4 cells in the juxta-midline area express $\alpha 2$-chimaerin. In control (Epha4 $\left.{ }^{+/ L a c z}\right)$ mice $(\boldsymbol{A})$, EphA4 $[\beta$-gal $(+)]$ cells in juxta-midline areas expressed $\alpha 2$-chimaerin $(\boldsymbol{D})$, but these cells were not found in the midline $(\boldsymbol{E})\left(n=4\right.$ sections from two mice). In EphA4KO (Epha4 $\left.{ }^{\text {Lacz/lacz }}\right)$ mice $(\boldsymbol{B})$, ectopic mildine-EphA4 cells expressed $\alpha 2$-chimaerin $(\boldsymbol{F})(n=4$ sections from two mice). In Chn $1 K 0$ mice (C), there was no staining of $\alpha 2$-chimaerin, confirming the specificity of anti- $\alpha 2$-chimaerin antibody $(\boldsymbol{G})(n=3$ sections from two mice). Arrows in $\boldsymbol{E}-\boldsymbol{G}$ indicate the position of the midline. Coronal sections of cervical cords at E15.5 were stained with anti- $\alpha 2$-chimaerin and anti- $\beta$-gal antibodies and DAPI. Scale bars: $\mathbf{A}-\mathbf{C}, 40 \mu \mathrm{m} ; \mathbf{D}-\mathbf{G}, 10 \mu \mathrm{m}$.

repelling juxta-midline EphA4 cells from the ephrinB3-expressing MB as a key downstream effector of ephrinB3-EphA4 signaling.

\section{$\alpha$-Chimaerin is critical for the maintenance of an intact MB}

In the developing vertebrate $\mathrm{CNS}$, the $\mathrm{MB}$, which comprises somata and processes of midline glia, plays a critical role in preventing aberrant midline crossing of axons. CST axons that originate from the motor cortex enter the contralateral side of the spinal cord (Miller, 1987), where they do not cross the midline again. The spinal MB expresses ephrinB3 to repel EphA4(+) CST axons and prevent midline crossing (Coonan et al., 2001; Kullander et al., 2001a, b; Yokoyama et al., 2001). In the dorsal DGM midline of Sp-Chn1KO mouse spinal cord, we observed numerous MB holes (Fig. 3) through which CST axons crossed the midline aberrantly (Figs. $1 D, E, 4 A-D$ ). It appears that the presence of $\mathrm{MB}$ holes is the cause of aberrant midline crossing of CST axons in these mice rather than a consequence because CST axons reach the spinal cord postnatally (Canty and Murphy, 2008), whereas MB holes were evident by E15.5 in Chn1KO mice (Fig. 5). Furthermore, although CST axons passed through the midline in $\mathrm{Cx}-\mathrm{Chn} 1 \mathrm{KO}$ mice (Fig. 1A,B), they did not form MB holes (Fig. $4 E, F)$.

Previous studies on midline axon guidance have mostly focused on the molecular mechanisms of axonal repulsion (and attraction) induced by the MB. In contrast, in the present study, we identified an important role of $\alpha$-chimaerin in establishing the MB. Specifically, we showed that, although $\alpha$-chimaerin is not required for the initial formation of the spinal $\mathrm{MB}$, it is required for its maintenance because the barrier was broken at E15.5 but was intact at E14.5 in Chn1KO mice (Fig. 5). Our results shed light on the importance of barrier maintenance for proper midline axon guidance.

\section{Maintenance of the MB by $\alpha$-chimaerin}

During the development of the spinal cord, the primitive lumen formed in the center of the neural tube by neurulation eventually transforms into the CC by gradually shrinking in size (Böhme, 1988; Sevc et al., 2009). EphrinB3 (+) midline glia were located at the dorsal end of the spinal midline at E13.5 and began to migrate ventrally after the shrinkage of the primitive lumen by E14.5 (Fig. 6A). At E14.5, ephrinB3 on these midline glia already formed the $\mathrm{MB}$ in both control and $\mathrm{Chn} 1 \mathrm{KO}$ mice (Fig. 5). At E15.5, the morphology of the lumen and the location of ephrinB3 $(+)$ glia somata were similar in control and Chn1KO mice. However, in Chn1 KO mice, the DF failed to invaginate, so the DGM expanded (Fig. 6A). In the dorsal DGM midline of Chn1KO mice, we observed numerous MB holes at E15.5 or later (Figs. 3, 5).

Intriguingly, many EphA4 $[\beta-\operatorname{gal}(+)]$ cells were located within MB holes in Chn1KO mice at E15.5 (Fig. 7). In the normal developing spinal cord, EphA4 cells were expressed in the juxtamidline area, but not within the midline (Fig. 6), as reported previously (Escalante et al., 2013; Paixão et al., 2013). In the absence of $\alpha$-chimaerin, EphA4 cells were located in the juxtamidline at E14.5, but several cells were mislocated in the midline at E15.5 (Fig. 6). In addition, MB holes simultaneously emerged around these EphA4 cells (Figs. 5, 7). These results suggest that $\alpha$-chimaerin prevents juxta-midline EphA4 cells from invading the $\mathrm{MB}$ during embryonic stages. This may occur by cell repulsion via the ephrinB3-EphA4- $\alpha$-chimaerin signaling pathway. We and others have reported previously that $\alpha$-chimaerin interacts with EphA4 in vivo and in vitro and mediates ephrinB3EphA4 forward signaling during motor circuit formation (Beg et al., 2007; Iwasato et al., 2007; Wegmeyer et al., 2007). Here, we showed that juxta-midline EphA4 cells express $\alpha 2$-chimaerin (Fig. 9A,D). Previous studies have reported that EphA4 cells aberrantly accumulated in the spinal midline in Epha4KO and SpEpha4KO mice (Restrepo et al., 2011; Paixão et al., 2013). Here, we showed that juxta-midline EphA4 cells in Epha4KO mice invade the midline during embryonic stages (Fig. 10) and MB holes are present around these ectopic midline-EphA4 cells at later stages such as P0 (Fig. 8). These results further support our hy- 

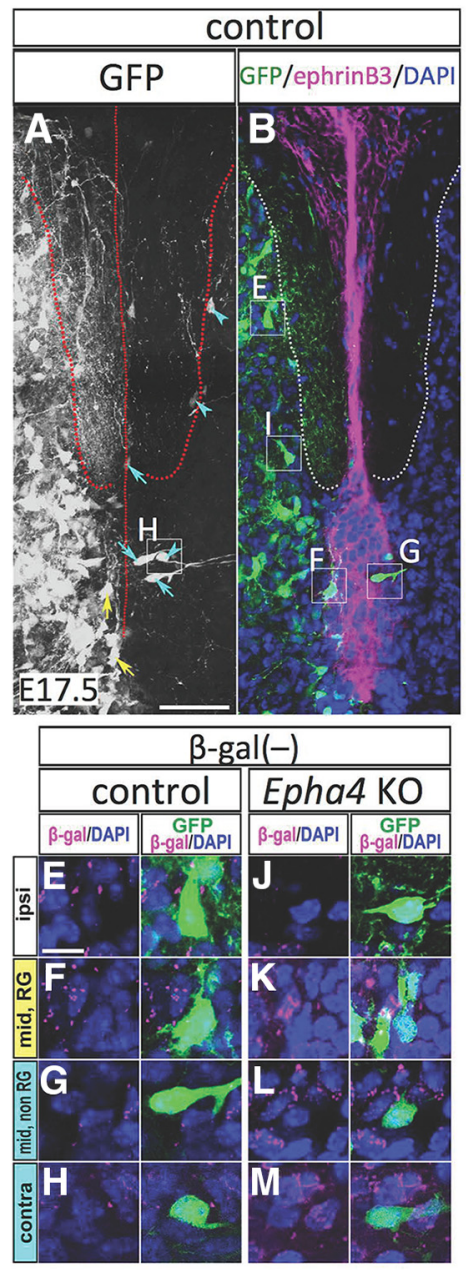

-gal(-)

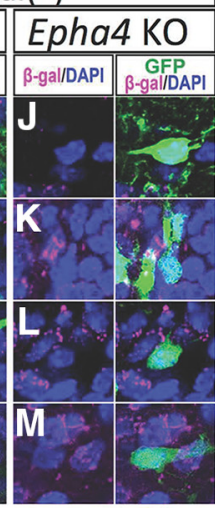

$\mathbf{R}$

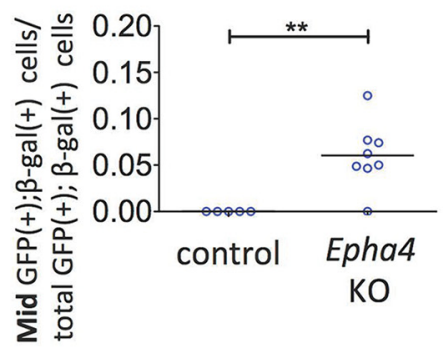

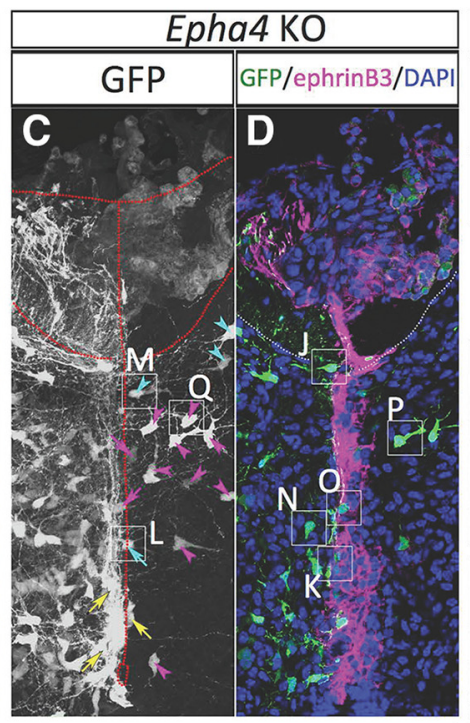
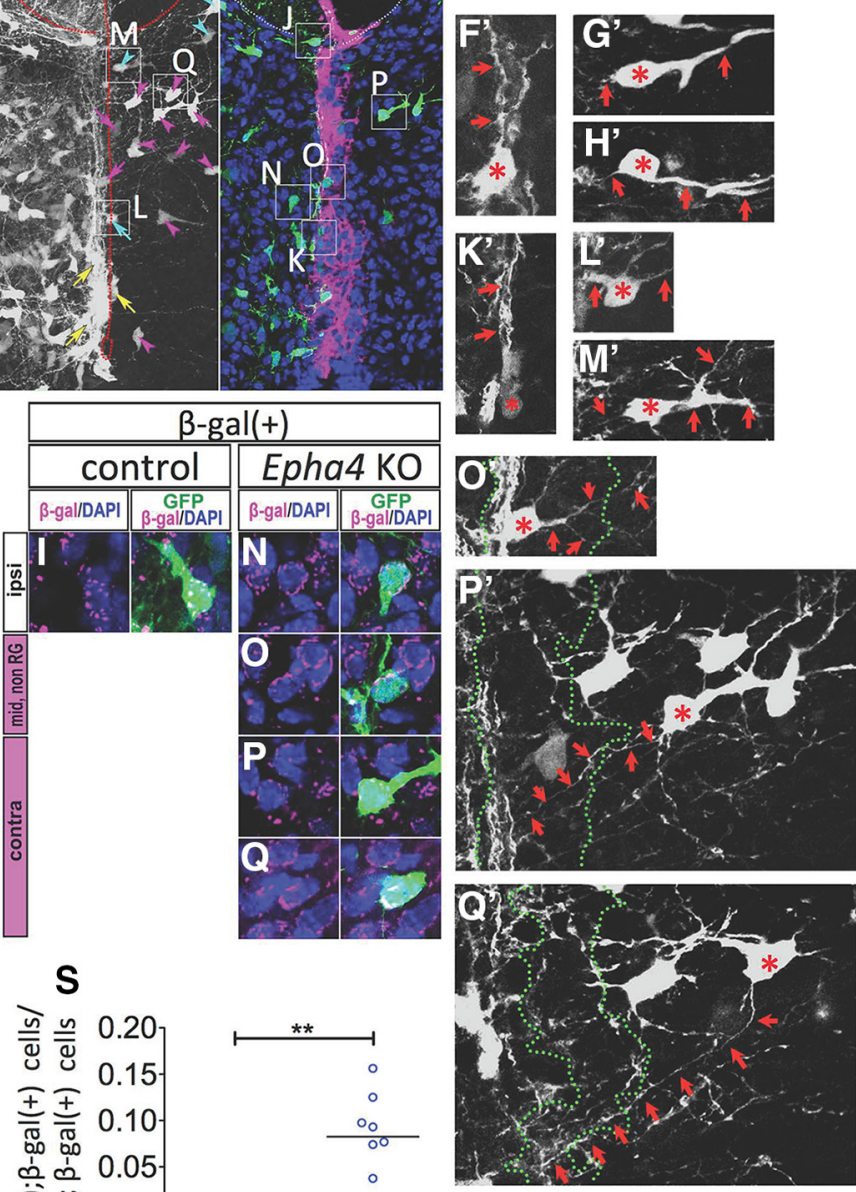

$\mathrm{S}$
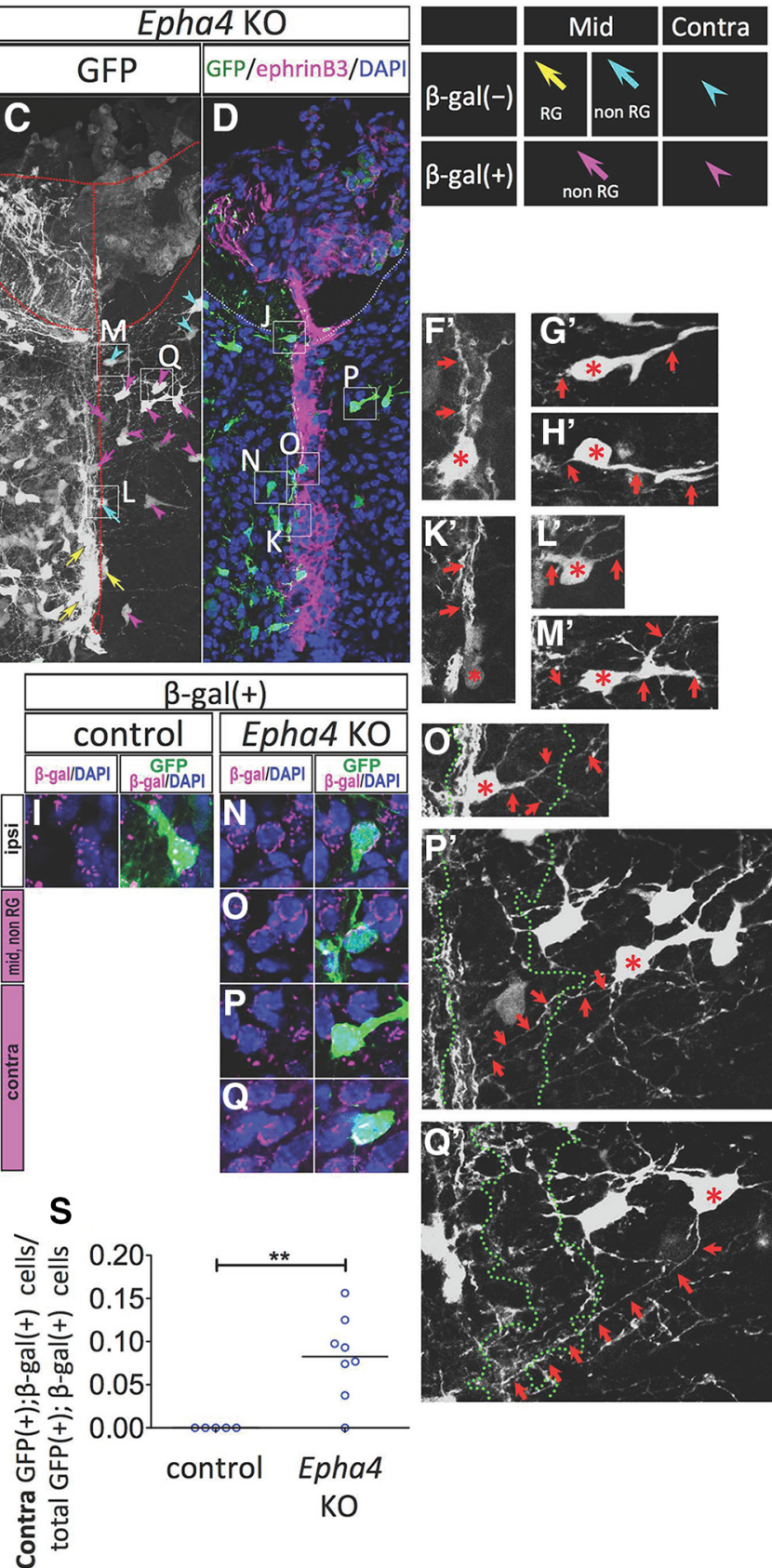

Figure 10. Midline invasion of EphA4 cells in Epha4KO mice (A-Q).A, Gfp expression vector was introduced unilaterally into the spinal cord of control (Epha4 ${ }^{+/ L a c Z}$ ) and Epha4KO (Epha4 ${ }^{\text {LacZ/LacZ) }}$ embryos at E11.5 using in utero electroporation and coronal sections of the cervical cord at E17.5 were stained using anti- $\beta$-gal and anti-ephrinB3 antibodies and DAPI. $\boldsymbol{B}$ and $\boldsymbol{D}$ are single-plane images obtained with confocal microscopy and $\boldsymbol{A}$ and $\boldsymbol{C}$ are $\mathbf{z}$-projection (35- $\mu \mathrm{m}$-thick) images. $\boldsymbol{E}-\boldsymbol{Q}$ are high-magnification images of boxes in $\boldsymbol{A}-\boldsymbol{D}$. $\boldsymbol{F}^{\prime}-\boldsymbol{H}^{\prime}, \boldsymbol{K}^{\prime}-\boldsymbol{M}^{\prime}$, and $\boldsymbol{O}^{\prime}-\boldsymbol{Q}^{\prime}, \boldsymbol{w}$ which are consistent with $\mathrm{GFP}(+)$ cells in $\boldsymbol{F}-\boldsymbol{H}, \boldsymbol{K}-\boldsymbol{M}$, and $\boldsymbol{0}-\boldsymbol{Q}$, respectively, indicate $z$-projection images of GFP signals. In the electroporated side (ipsi) of both genotypes, GFP(+); $\beta$-gal $(-)$ (e.g., $\boldsymbol{E}$ and $\boldsymbol{J})$ and GFP $(+) ; \beta$-gal $(+)$ cells (e.g., $\boldsymbol{I}$ and $\boldsymbol{N}$ ) were found. In the ephrinB3 $(+)$ MB of both genotypes, some GFP $(+) ; \beta$-gal $(-)$ cells appeared as midline radial glia (RG; yellow arrows in $\boldsymbol{A}$ and $\boldsymbol{C} ; \boldsymbol{F}$ and $\boldsymbol{K}$ ), because they extend their processes along the DV axis (arrows in $\boldsymbol{F}^{\prime}$ and $\boldsymbol{K}^{\prime}$ ) and other GFP(+); $\beta$-gal ( - ) cells (cyan arrows in $\boldsymbol{A}$ and $\boldsymbol{C} ; \boldsymbol{G}, \boldsymbol{L}$ ) were nonradial glial (non-RG) cells that extend their processes orthogonally to the DV axis (arrows in $\mathbf{G}^{\prime}$ and $\boldsymbol{L}^{\prime}$ ). Conversely, in the midline (mid), GFP(+); $\beta$-gal $(+)$ cells (magenta arrows in $\boldsymbol{C}$; e.g., $\left.\mathbf{0}\right)$ were found only in Epha4K0 mice and they extended their processes orthogonally to the DV axis (arrows in $\mathbf{O}^{\prime}$ ). In the contralateral (contra) side, both genotypes had GFP $(+)$; $\beta$-gal $(-$ ) cells extending their processes orthogonally to the DV axis (cyan arrowheads in $\boldsymbol{A}$ and $\boldsymbol{C}$; e.g., $\boldsymbol{H}$ and $\boldsymbol{M}$; arrows in $\boldsymbol{H}^{\prime}$ and $\boldsymbol{M}^{\prime}$ ), but only Epha4KO mice had GFP $(+)$; $\beta$-gal $(+)$ cells $($ magenta arrowheads in $\boldsymbol{C}$; e.g., $\boldsymbol{P}$ ), which projected axon-like processes to the ipsilateral side (arrows in $\boldsymbol{P}^{\prime}$ and $\boldsymbol{Q}^{\prime}$ ). Asterisks in $\boldsymbol{F}^{\prime}-\boldsymbol{H}^{\prime}, \boldsymbol{K}^{\prime}-\boldsymbol{M}^{\prime}$, and $\boldsymbol{O}^{\prime}-\boldsymbol{Q}^{\prime}$ indicate somata. The MB is outlined with green dotted lines in $\boldsymbol{O}^{\prime}-\mathbf{Q}^{\prime}$. Scale bars: $\boldsymbol{A}-\boldsymbol{D}, 50 \boldsymbol{\mu m} ; \boldsymbol{E}-\mathbf{Q}$, $\boldsymbol{F}^{\prime}-\boldsymbol{H}^{\prime}, \boldsymbol{K}^{\prime}-\boldsymbol{M}^{\prime}, \boldsymbol{O}^{\prime}-\boldsymbol{Q}^{\prime}, 10 \mu \mathrm{m} . \boldsymbol{R}, \mathbf{S}$, Ratio of midline (Mid) GFP(+); $\beta$-gal $(+)$ cells in total GFP( + ); $\beta$-gal $(+)$ cells in each section $(\boldsymbol{R})$ and ratio of contralateral (Contra) GFP( + ); $\beta$-gal $(+)$ cells in total GFP $(+) ; \beta$-gal $(+)$ cells in each section $(S)$ are shown (control: $n=5$ sections from 3 mice; EphA4K0: $n=8$ sections from 4 mice). 0nly in Epha4KO mice were some GFP $(+) ; \beta$-gal $(+)$ cells distributed in the midline and contralateral areas. Data are represented as scatter plot and mean. Mann-Whitney $U$ test, ${ }^{* *} p<0.01$.

pothesis that impaired EphA4- $\alpha$-chimaerin signaling in the juxta-midline EphA4 cells allows these cells to break into the midline in Chn1KO and Epha4KO mice, resulting in MB hole formation. Alternatively, MB holes may be formed by an im- paired EphA4- $\alpha$-chimaerin signaling in ephrinB3 $(+)$ midline radial glia. However, we think that this scenario is unlikely because, in normal mice, midline radial glia have little EphA4 expression (Figs. 6, 9, 10). Therefore, we propose that spinal 


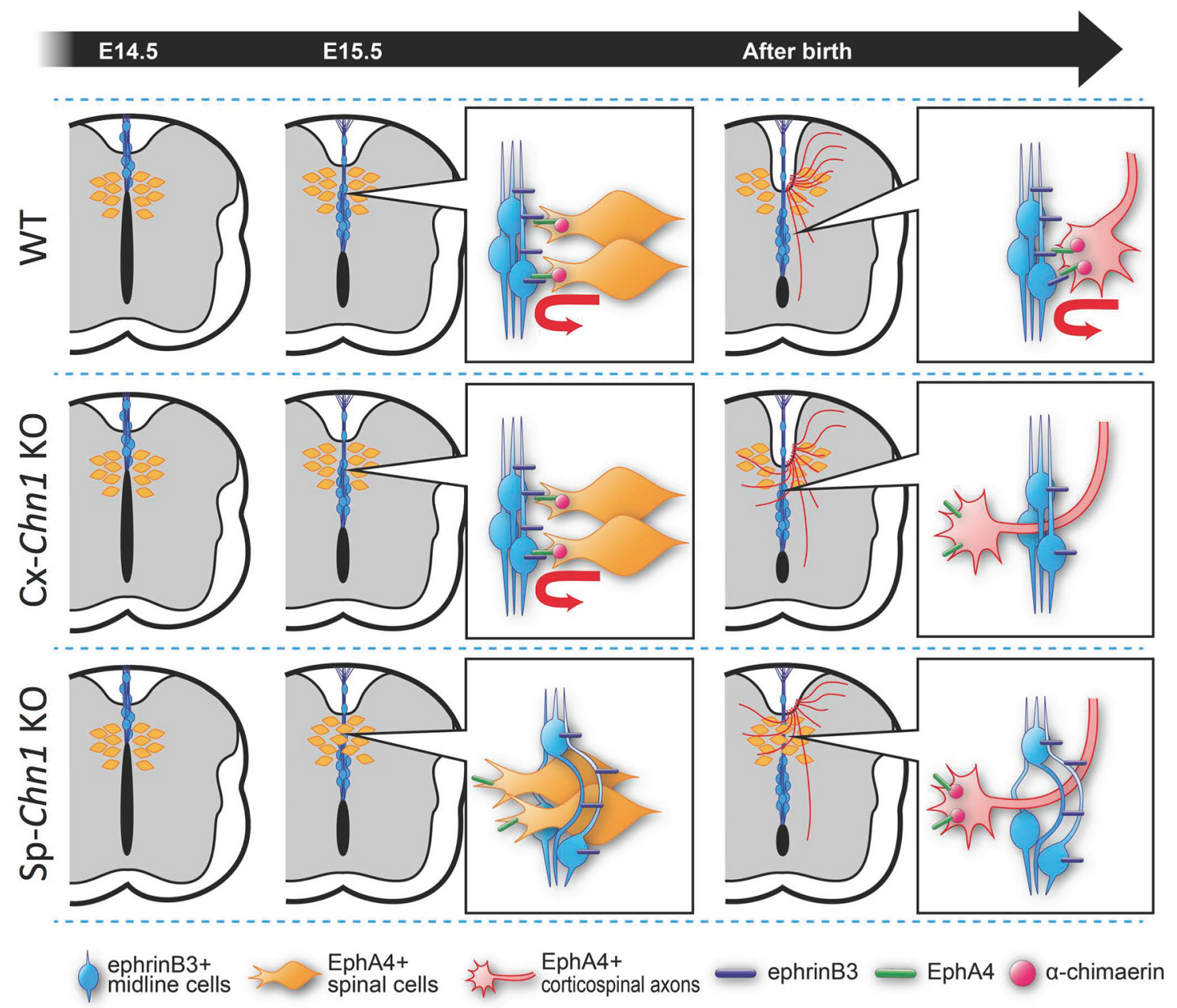

Figure 11. Schematic diagram of dual roles of $\alpha$-chimaerin in spinal midline guidance of corticospinal axons. During the embryonic development of wild-type mice, $\alpha$-chimaerin in EphA4(+) cells plays an important role in establishing an intact MB by repelling EphA4(+) cells from the ephrinB3(+) midline. The resulting intact MB repels EphA4(+) CST axons during postnatal development. In C $x$-Chn7KO mice, although the MB is intact, EphA4(+) CST axons aberrantly cross the midline because these axons cannot be repelled by ephrinB3 on the MB because of a lack of $\alpha$-chimaerin in the axonal tips. During embryonic development in Sp-Chn 1KO mice, EphA4(+) cells invade the midline because these cells cannot be repelled by the ephrinB3(+) midline due to lack of $\alpha$-chimaerin. EphA4(+) cell invasion makes MB holes. Postnatally, EphA4(+) CST axons then cross the midline aberrantly through these MB holes.

$\alpha$-chimaerin maintains the intact MB by mediating ephrinB3EphA4 cell-repulsive signaling in juxta-midline EphA4 cells.

\section{Dual roles of $\alpha$-chimaerin for corticospinal axon midline guidance}

We have reported previously that cultured cortical neurons devoid of $\alpha$-chimaerin suppressed ephrinB3-induced growth cone collapse (Iwasato et al., 2007). Here, we showed that Cx-Chn1 KO mice exhibit aberrant midline crossing of CST axons in the spinal cord (Fig. $1 A, B$ ), with an intact ephrinB3(+) MB (Figs. $3 E$, $4 E, F)$. Therefore, $\alpha$-chimaerin in cortical neurons is a key mediator of ephrinB3-EphA4 signaling for axonal repulsion. Without this $\alpha$-chimaerin function, EphA4-expressing CST axons cannot be repulsed by the ephrinB3(+) MB in the spinal cord and cross the midline aberrantly (Fig. 11).

In the present study, we showed that $\alpha$-chimaerin also has another function in CST axon midline guidance: $\alpha$-chimaerin in spinal neurons acts as a key mediator of ephrinB3-EphA4 signaling for cell repulsion. Without this $\alpha$-chimaerin function, EphA4-expressing juxta-midline cells (mostly neurons) cannot be repulsed by the ephrinB3(+) $\mathrm{MB}$ in the spinal cord and break into the midline to form MB holes. Later in postnatal develop- ment, EphA4-expressing CST axons cross the midline aberrantly through these MB holes (Fig. 11). Therefore, $\alpha$-chimaerin in the embryonic spinal cord regulates postnatal CST axon midline guidance indirectly. CST axons may cross the spinal midline actively through $\mathrm{MB}$ holes using EphA4(+) cells located in $\mathrm{MB}$ holes as guide post cells (Chao et al., 2009). However, we think it is more likely that CST axons cross the midline passively through ephrinB3(-) spaces (i.e., MB holes) because many CST axons crossed the midline in $\mathrm{Sp}-\mathrm{Chn} 1 \mathrm{KO}$ mice at positions where there were no cells (Fig. 4C).

Therefore, two spatially (cortical cell axon vs spinal cord cell), temporally (postnatal vs embryonic), and physiologically (axonal repulsion vs cell repulsion) distinct functions of $\alpha$-chimaerin are essential for proper CST axon midline guidance in the spinal cord.

\section{Roles of $\alpha$-chimaerin in CNS development and function}

$\alpha$-Chimaerin is a RacGAP that regulates actin dynamics. The discovery and analyses of spontaneous null mutant mice of $\mathrm{Chn} 1$ identified an in vivo function of $\alpha$-chimaerin (Iwasato et al., 2007). $\alpha$-Chimaerin regulates the midline guidance of CST axons and local spinal circuits and a loss-of-function of $\alpha$-chimaerin 
results in a hopping gait (Iwasato et al., 2007). Similar results were obtained in $\mathrm{Chn} 1 \mathrm{KO}$ mice generated independently by three groups of investigators, including ours (Beg et al., 2007; Iwasato et al., 2007; Wegmeyer et al., 2007), and in an in vitro model (Shi et al., 2007). $\alpha$-Chimaerin regulates axonal pathfinding of both spinal lateral motor column neurons innervating ventral limb muscle as a downstream molecule of EphA signaling (Kao et al., 2015) and oculomotor neurons innervating extraocular muscles as a downstream molecule of Semaphorin signaling (Ferrario et al., 2012; Clark et al., 2013). We also reported that $\alpha 2$-chimaerin is important for the regulation of locomotor activity (Iwata et al., 2014), the ability of contextual learning (Iwata et al., 2014), and the spine morphogenesis of hippocampal neurons (Iwata et al., 2015) in mice. In humans, gain-of-function mutations in CHN1 cause Duane's retraction syndrome (Miyake et al., 2008) and a single nucleotide polymorphism in the CHN1 locus is associated with autistic traits and the arithmetic ability of healthy humans (Iwata et al., 2014). A recent study using a knockdown approach suggested that $\alpha$-chimaerin plays a role in the multipolar-bipolar transition of cortical neurons in a RacGAP-independent manner (Ip et al., 2011). In the current study, we provide evidence for a novel role of $\alpha$-chimaerin in neural circuit formation. Spinal $\alpha$-chimaerin is critical for the prevention of the MB invasion of spinal cells, which is essential for the maintenance of an intact MB and proper midline guidance of CST axons. Therefore, $\alpha$-chimaerin plays important roles in a various aspects of neural circuit development and function.

\section{References}

Badaloni A, Bonanomi D, Albieri I, Givogri I, Bongarzone E, Valtorta F, Consalez GG (2007) Transgenic mice expressing a dual, CRE-inducible reporter for the analysis of axon guidance and synaptogenesis. Genesis 45:405-412. CrossRef Medline

Beg AA, Sommer JE, Martin JH, Scheiffele P (2007) alpha2-Chimaerin is an essential EphA4 effector in the assembly of neuronal locomotor circuits. Neuron 55:768-778. CrossRef Medline

Böhme G (1988) Formation of the central canal and dorsal glial septum in the spinal cord of the domestic cat. J Anat 159:37-47. Medline

Borgius L, Nishimaru H, Caldeira V, Kunugise Y, Löw P, Reig R, Itohara S, Iwasato T, Kiehn O (2014) Spinal glutamatergic neurons defined by EphA4 signaling are essential components of normal locomotor circuits. J Neurosci 34:3841-3853. CrossRef Medline

Cai D, Cohen KB, Luo T, Lichtman JW, Sanes JR (2013) Improved tools for the Brainbow toolbox. Nat Methods 10:540-547. CrossRef Medline

Canty AJ, Murphy M (2008) Molecular mechanisms of axon guidance in the developing corticospinal tract. Prog Neurobiol 85:214-235. CrossRef Medline

Chao DL, Ma L, Shen K (2009) Transient cell-cell interactions in neural circuit formation. Nat Rev Neurosci 10:262-271. CrossRef Medline

Charron F, Stein E, Jeong J, McMahon AP, Tessier-Lavigne M (2003) The morphogen sonic hedgehog is an axonal chemoattractant that collaborates with netrin-1 in midline axon guidance. Cell 113:11-23. CrossRef Medline

Chédotal A (2011) Further tales of the midline. Curr Opin Neurobiol 21: 68-75. CrossRef Medline

Clark C, Austen O, Poparic I, Guthrie S (2013) alpha2-Chimaerin regulates a key axon guidance transition during development of the oculomotor projection. J Neurosci 33:16540-16551. CrossRef Medline

Comer JD, Pan FC, Willet SG, Haldipur P, Millen KJ, Wright CV, Kaltschmidt JA (2015) Sensory and spinal inhibitory dorsal midline crossing is independent of Robo3. Front Neural Circuits 9:36. CrossRef Medline

Coonan JR, Greferath U, Messenger J, Hartley L, Murphy M, Boyd AW, Dottori M, Galea MP, Bartlett PF (2001) Development and reorganization of corticospinal projections in EphA4 deficient mice. J Comp Neurol 436:248-262. Medline

Dong JM, Smith P, Hall C, Lim L (1995) Promoter region of the transcriptional unit for human alpha 1-chimaerin, a neuron-specific GTPase- activating protein for p21rac. Eur J Biochem 227:636-646. CrossRef Medline

Dottori M, Hartley L, Galea M, Paxinos G, Polizzotto M, Kilpatrick T, Bartlett PF, Murphy M, Köntgen F, Boyd AW (1998) EphA4 (Sek1) receptor tyrosine kinase is required for the development of the corticospinal tract. Proc Natl Acad Sci U S A 95:13248-13253. CrossRef Medline

Erskine L, Herrera E (2014) Connecting the retina to the brain. ASN Neuro 6.

Escalante A, Murillo B, Morenilla-Palao C, Klar A, Herrera E (2013) Zic2dependent axon midline avoidance controls the formation of major ipsilateral tracts in the CNS. Neuron 80:1392-1406. CrossRef Medline

Ferrario JE, Baskaran P, Clark C, Hendry A, Lerner O, Hintze M, Allen J, Chilton JK, Guthrie S (2012) Axon guidance in the developing ocular motor system and Duane retraction syndrome depends on Semaphorin signaling via alpha2-chimaerin. Proc Natl Acad Sci U S A 109:1466914674. CrossRef Medline

Hall C, Michael GJ, Cann N, Ferrari G, Teo M, Jacobs T, Monfries C, Lim L (2001) alpha2-chimaerin, a Cdc42/Racl regulator, is selectively expressed in the rat embryonic nervous system and is involved in neuritogenesis in N1E-115 neuroblastoma cells. J Neurosci 21:5191-5202. Medline

Hamilton LK, Truong MK, Bednarczyk MR, Aumont A, Fernandes KJ (2009) Cellular organization of the central canal ependymal zone, a niche of latent neural stem cells in the adult mammalian spinal cord. Neuroscience 164:1044-1056. CrossRef Medline

Ip JP, Shi L, Chen Y, Itoh Y, Fu WY, Betz A, Yung WH, Gotoh Y, Fu AK, Ip NY (2011) alpha2-chimaerin controls neuronal migration and functioning of the cerebral cortex through CRMP-2. Nat Neurosci 15:3947. CrossRef Medline

Iwasato T, Datwani A, Wolf AM, Nishiyama H, Taguchi Y, Tonegawa S, Knöpfel T, Erzurumlu RS, Itohara S (2000) Cortex-restricted disruption of NMDAR1 impairs neuronal patterns in the barrel cortex. Nature 406: 726-731. CrossRef Medline

Iwasato T, Katoh H, Nishimaru H, Ishikawa Y, Inoue H, Saito YM, Ando R, Iwama M, Takahashi R, Negishi M, Itohara S (2007) Rac-GAP alphachimerin regulates motor-circuit formation as a key mediator of EphrinB3/EphA4 forward signaling. Cell 130:742-753. CrossRef Medline

Iwasato T, Inan M, Kanki H, Erzurumlu RS, Itohara S, Crair MC (2008) Cortical adenylyl cyclase 1 is required for thalamocortical synapse maturation and aspects of layer IV barrel development. J Neurosci 28:59315943. CrossRef Medline

Iwata R, Ohi K, Kobayashi Y, Masuda A, Iwama M, Yasuda Y, Yamamori H, Tanaka M, Hashimoto R, Itohara S, Iwasato T (2014) RacGAP alpha2chimaerin function in development adjusts cognitive ability in adulthood. Cell Rep 8:1257-1264. CrossRef Medline

Iwata R, Matsukawa H, Yasuda K, Mizuno H, Itohara S, Iwasato T (2015) Developmental RacGAP alpha2-chimaerin signaling is a determinant of the morphological features of dendritic spines in adulthood. J Neurosci 35:13728-13744. CrossRef Medline

Kamiyama T, Kameda H, Murabe N, Fukuda S, Yoshioka N, Mizukami H, Ozawa K, Sakurai M (2015) Corticospinal tract development and spinal cord innervation differ between cervical and lumbar targets. J Neurosci 35:1181-1191. CrossRef Medline

Kao TJ, Nicholl GC, Johansen JA, Kania A, Beg AA (2015) alpha2-chimaerin is required for Eph receptor-class-specific spinal motor axon guidance and coordinate activation of antagonistic muscles. J Neurosci 35:23442357. CrossRef Medline

Kato M, Yamanouchi K, Ikawa M, Okabe M, Naito K, Tojo H (1999) Efficient selection of transgenic mouse embryos using EGFP as a marker gene. Mol Reprod Dev 54:43-48. Medline

Katori S, Hamada S, Noguchi Y, Fukuda E, Yamamoto T, Yamamoto H, Hasegawa S, Yagi T (2009) Protocadherin-alpha family is required for serotonergic projections to appropriately innervate target brain areas. J Neurosci 29:9137-9147. CrossRef Medline

Kobayashi Y, Sano Y, Vannoni E, Goto H, Suzuki H, Oba A, Kawasaki H, Kanba S, Lipp HP, Murphy NP, Wolfer DP, Itohara S (2013) Genetic dissection of medial habenula-interpeduncular nucleus pathway function in mice. Front Behav Neurosci 7:17. CrossRef Medline

Kozma R, Ahmed S, Best A, Lim L (1996) The GTPase-activating protein n-chimaerin cooperates with Racl and Cdc42Hs to induce the formation of lamellipodia and filopodia. Mol Cell Biol 16:5069-5080. CrossRef Medline

Kullander K, Mather NK, Diella F, Dottori M, Boyd AW, Klein R (2001a) 
Kinase-dependent and kinase-independent functions of EphA4 receptors in major axon tract formation in vivo. Neuron 29:73-84. CrossRef Medline

Kullander K, Croll SD, Zimmer M, Pan L, McClain J, Hughes V, Zabski S, DeChiara TM, Klein R, Yancopoulos GD, Gale NW (2001b) Ephrin-B3 is the midline barrier that prevents corticospinal tract axons from recrossing, allowing for unilateral motor control. Genes Dev 15:877-888. CrossRef Medline

Kullander K, Butt SJ, Lebret JM, Lundfald L, Restrepo CE, Rydström A, Klein R, Kiehn O (2003) Role of EphA4 and EphrinB3 in local neuronal circuits that control walking. Science 299:1889-1892. CrossRef Medline

Leighton PA, Mitchell KJ, Goodrich LV, Lu X, Pinson K, Scherz P, Skarnes WC, Tessier-Lavigne M (2001) Defining brain wiring patterns and mechanisms through gene trapping in mice. Nature 410:174-179. CrossRef Medline

Long H, Sabatier C, Ma L, Plump A, Yuan W, Ornitz DM, Tamada A, Murakami F, Goodman CS, Tessier-Lavigne M (2004) Conserved roles for Slit and Robo proteins in midline commissural axon guidance. Neuron 42:213-223. CrossRef Medline

Longair MH, Baker DA, Armstrong JD (2011) Simple Neurite Tracer: open source software for reconstruction, visualization and analysis of neuronal processes. Bioinformatics 27:2453-2454. CrossRef Medline

Marichal N, García G, Radmilovich M, Trujillo-Cenóz O, Russo RE (2012) Spatial domains of progenitor-like cells and functional complexity of a stem cell niche in the neonatal rat spinal cord. Stem Cells 30:2020-2031. CrossRef Medline

McDermott KW, Barry DS, McMahon SS (2005) Role of radial glia in cytogenesis, patterning and boundary formation in the developing spinal cord. J Anat 207:241-250. CrossRef Medline

Meijering E, Jacob M, Sarria JC, Steiner P, Hirling H, Unser M (2004) Design and validation of a tool for neurite tracing and analysis in fluorescence microscopy images. Cytometry A 58:167-176. Medline

Miller MW (1987) The origin of corticospinal projection neurons in rat. Exp Brain Res 67:339-351. Medline

Miyake N, et al. (2008) Human CHN1 mutations hyperactivate alpha2chimaerin and cause Duane's retraction syndrome. Science 321:839-843. CrossRef Medline

Mokry J, Ehrmann J, Karbanova J, Cizkova D, Soukup T, Suchanek J, Filip S, Kolar Z (2008) Expression of intermediate filament nestin in blood vessels of neural and non-neural tissues. Acta Medica (Hradec Kralove) 51: 173-179. Medline

Omoto S, Ueno M, Mochio S, Yamashita T (2011) Corticospinal tract fibers cross the ephrin-B3-negative part of the midline of the spinal cord after brain injury. Neurosci Res 69:187-195. CrossRef Medline

Orlino EN Jr, Wong CM, Phelps PE (2000) L1 and GAD65 are expressed on dorsal commissural axons in embryonic rat spinal cord. Brain Res Dev Brain Res 125:117-130. CrossRef Medline

Paixão S, Balijepalli A, Serradj N, Niu J, Luo W, Martin JH, Klein R (2013) EphrinB3/EphA4-mediated guidance of ascending and descending spinal tracts. Neuron 80:1407-1420. CrossRef Medline

Pignata A, Ducuing H, Castellani V (2016) Commissural axon navigation: Control of midline crossing in the vertebrate spinal cord by the Semaphorin3B signaling. Cell Adh Migr 10:604-617. CrossRef Medline

Restrepo CE, Margaryan G, Borgius L, Lundfald L, Sargsyan D, Kiehn O (2011) Change in the balance of excitatory and inhibitory midline fiber crossing as an explanation for the hopping phenotype in EphA4 knockout mice. Eur J Neurosci 34:1102-1112. CrossRef Medline

Sakai N, Kaprielian Z (2012) Guidance of longitudinally projecting axons in the developing central nervous system. Front Mol Neurosci 5:59. CrossRef Medline

Schaeren-Wiemers N, Gerfin-Moser A (1993) A single protocol to detect transcripts of various types and expression levels in neural tissue and cultured cells: in situ hybridization using digoxigenin-labelled cRNA probes. Histochemistry 100:431-440. CrossRef Medline

Serafini T, Colamarino SA, Leonardo ED, Wang H, Beddington R, Skarnes WC, Tessier-Lavigne M (1996) Netrin-1 is required for commissural axon guidance in the developing vertebrate nervous system. Cell 87:10011014. CrossRef Medline

Sevc J, Daxnerová Z, Miklosová M (2009) Role of radial glia in transformation of the primitive lumen to the central canal in the developing rat spinal cord. Cell Mol Neurobiol 29:927-936. CrossRef Medline

Shi L, Fu WY, Hung KW, Porchetta C, Hall C, Fu AK, Ip NY (2007) Alpha2chimaerin interacts with EphA4 and regulates EphA4-dependent growth cone collapse. Proc Natl Acad Sci U S A 104:16347-16352. CrossRef Medline

Snow DM, Steindler DA, Silver J (1990) Molecular and cellular characterization of the glial roof plate of the spinal cord and optic tectum: a possible role for a proteoglycan in the development of an axon barrier. Dev Biol 138:359-376. CrossRef Medline

Wegmeyer H, Egea J, Rabe N, Gezelius H, Filosa A, Enjin A, Varoqueaux F, Deininger K, Schnütgen F, Brose N, Klein R, Kullander K, Betz A (2007) EphA4-dependent axon guidance is mediated by the RacGAP alpha2chimaerin. Neuron 55:756-767. CrossRef Medline

Witschi R, Johansson T, Morscher G, Scheurer L, Deschamps J, Zeilhofer HU (2010) Hoxb8-Cre mice: A tool for brain-sparing conditional gene deletion. Genesis 48:596-602. CrossRef Medline

Yokoyama N, Romero MI, Cowan CA, Galvan P, Helmbacher F, Charnay P, Parada LF, Henkemeyer M (2001) Forward signaling mediated by ephrin-B3 prevents contralateral corticospinal axons from recrossing the spinal cord midline. Neuron 29:85-97. CrossRef Medline 